\title{
The Canadian Beaufort Shelf trophic structure: evaluating an ecosystem modelling approach by comparison with observed stable isotopic structure $^{1}$
}

\author{
C. Hoover, C. Giraldo, A. Ehrman, K.D. Suchy, S.A. MacPhee, J. Brewster, \\ J.D. Reist, M. Power, H. Swanson, and L. Loseto
}

\begin{abstract}
Climate-driven impacts on marine trophic pathways worldwide are compounded by sea-ice loss at northern latitudes. For the Arctic, current information describing food-web linkages is fragmented, and there is a need for tools that can describe overarching trophic structure despite limited species-specific data. Here, we tested the ability of a mass-balanced ecosystem model (Ecopath with Ecosim, EwE) to reconstruct the trophic hierarchy of 31 groups, from primary producers to polar bears, in the Canadian Beaufort Sea continental shelf. Trophic level (TL) estimates from EwE were compared with those derived from two nitrogen stable isotope (SI) modelling approaches (SI linear and scaled) to assess EwE accuracy, using a data set of $642 \delta^{15} \mathrm{~N}$ observations across 282 taxa. TLs from EwE were strongly, positively related to those from both SI models $\left(R^{2}>0.80\right)$. EwE performed well (within $0.2 \mathrm{TL}$ ) for groups with relatively well-known diets or for taxa characterized by fewer trophic connections (e.g., primary consumers). Performance was worse $(>0.5 \mathrm{TL})$ for species groups aggregated at coarse taxonomic levels, those with poorly documented diets, and for anadromous fishes. Comparisons with SI models suggested that the scaled approach can overestimate the TL of top predators if ecosystem-specific information is not considered.
\end{abstract}

Key words: Ecopath with Ecosim, stable isotopes of nitrogen, trophic level, marine ecosystem.

\footnotetext{
Received 17 September 2020. Accepted 11 July 2021.

C. Hoover*, ${ }^{* \ddagger}$ and J. Brewster. Centre for Earth Observation Science, University of Manitoba, Winnipeg, MB R3T 2N2, Canada; Fisheries and Oceans Canada, Central and Arctic Region, 501 University Crescent, Winnipeg, MB R3T 2N6, Canada.

C. Giraldo.* Fisheries and Oceans Canada, Central and Arctic Region, 501 University Crescent, Winnipeg, MB R3T 2N6, Canada; Ifremer, HMMN, Centre Manche - Mer du Nord, BP 669, F-62 321 Boulogne sur Mer, France.

A. Ehrman,* S.A. MacPhee, ${ }^{\dagger}$ J.D. Reist, and L. Loseto. ${ }^{\dagger}$ Fisheries and Oceans Canada, Central and Arctic Region, 501 University Crescent, Winnipeg, MB R3T 2N6, Canada.

K.D. Suchy. ${ }^{\S}$ Department of Geography, University of Victoria, Victoria, BC V8W 2Y2, Canada.

M. Power ${ }^{\dagger}$ and H. Swanson. ${ }^{\dagger}$ Biology Department, University of Waterloo, 200 University Avenue W, Waterloo, ON N2L 3G1, Canada.

Corresponding author: Carie Hoover (email: Carie.Hoover@dal.ca).

*These authors share first authorship.

${ }^{\dagger}$ Carie Hoover and Shannon A. MacPhee served as Guest Editors, Michael Power and Heidi Swanson served as Associate Editors, and Lisa Loseto served as Editor-in-Chief at the time of manuscript review and acceptance; peer review and editorial decisions regarding this manuscript were handled by Melissa Lafrenière and Tiff-Annie Kenny.

${ }^{\ddagger}$ Present address: Marine Affairs Program, Dalhousie University, Halifax, NS B3H 4R2, Canada.

SPresent address: Department of Earth, Ocean, and Atmospheric Sciences, The University of British Columbia, Vancouver, BC V6T 1Z4, Canada.

${ }^{1}$ This article is part of a Virtual Special Issue entitled "Tarium Niryutait Marine Protected Area".

(c) 2021 The Author(s). This work is licensed under a Creative Commons Attribution 4.0 International License (CC BY 4.0), which permits unrestricted use, distribution, and reproduction in any medium, provided the original author(s) and source are credited.
} 
Résumé : Les impacts du climat sur les voies trophiques marines à travers le monde sont aggravés par la perte de glace de mer aux latitudes nord. Pour l'Arctique, l'information actuelle décrivant les liens du réseau alimentaire est fragmentée, et il existe un besoin d'outils capables de décrire la structure trophique globale malgré des données limitées spécifiques aux espèces. Les auteurs ont testé ici la capacité d'un modèle écosystémique à masse équilibrée (Ecopath avec Ecosim, EwE) à reconstruire la hiérarchie trophique de 31 groupes, des producteurs primaires aux ours polaires, sur le plateau continental de la mer de Beaufort canadienne. Les estimations du niveau trophique (NT) provenant d'EwE ont été comparées à celles dérivées de deux approches de modélisation des isotopes stables (IS) de l'azote (IS linéaire et échelonné) afin d'évaluer la précision d'EwE, en utilisant un ensemble de données de 642 observations de $\delta^{15} \mathrm{~N}$ pour 282 taxons. Les NT d'EwE étaient fortement et positivement liés à ceux des deux modèles d'IS $\left(R^{2}>0,80\right)$. EwE a obtenu de bonnes performances (à l'intérieur de 0,2 NT) pour les groupes dont le régime alimentaire est relativement bien connu ou pour les taxons caractérisés par moins de connexions trophiques (par exemple, les consommateurs primaires). La performance était moins bonne $(>0,5 \mathrm{NT})$ pour les groupes d'espèces agrégés à des niveaux taxonomiques grossiers, pour ceux dont le régime alimentaire est mal documenté et pour les poissons anadromes. Les comparaisons avec les modèles d'IS suggèrent que l'approche scalaire peut surestimer le NT des prédateurs supérieurs si les informations spécifiques à l'écosystème ne sont pas prises en compte. [Traduit par la Rédaction]

Mots-clés : Ecopath avec Ecosim, isotopes stables de l'azote, niveau trophique, écosystème marin.

\section{Introduction}

Severe and rapid climate-driven changes in temperature, sea-ice cover, nutrient delivery, and physical mixing dynamics have altered energy pathways in Arctic marine ecosystems, leading to significant changes in species distributions, food webs, and ecosystem function (e.g., Hoegh-Guldberg and Bruno 2010; Kortsch et al. 2015; Frainer et al. 2017). Existing baseline information on ecosystem functioning in the Arctic is both temporally and spatially limited (Wassmann et al. 2011). Current information describing Arctic food-web linkages and predator-prey relationships is fragmented, and data availability varies greatly depending on the taxa and study approach (e.g., stomach contents analysis, trait-based classifications, biochemical tracers) (Matley et al. 2015; Kohlbach et al. 2017). Effective tools that can integrate available ecological information and account for data-poor species are, therefore, necessary to characterize present food-web structure and to predict implications of climate change.

To that end, ecosystem modelling software, such as Ecopath with Ecosim (EwE) (Christensen et al. 2005; Buszowski et al. 2007), can approximate food-web structure using both locally relevant and inferred data, and can facilitate comparisons within and among ecosystems (Walters et al. 1997; Plaganyi 2007; Colléter et al. 2015; Steenbeek et al. 2015). EwE uses mass-balance approaches (Plaganyi 2007) to estimate key food-web parameters that can describe structure and function of an ecosystem, and can include food-web members ranging from primary producers to top predators (Walters et al. 1997; Christensen et al. 2007).

An EwE ecosystem model was constructed for the Canadian Beaufort Sea (CBS) shelf to integrate species-specific research projects into a holistic view of the food web (Hoover et al. 2021). The region is relatively data dense for the Canadian Arctic, having been subject to various historical and ongoing large-scale ecosystem studies (see Cobb et al. 2008). However, the quantity, types, spatial scales, and temporal coverage of biomass and dietary data used to construct the EwE model varied among taxa and ecosystem components and, in some cases, it was necessary to infer parameters from nearby Arctic areas (e.g., deeper Beaufort Sea, Chukchi Sea, Amundsen Gulf). In general, EwE model quality is limited by 
data quality and quantity (Plaganyi and Butterworth 2004). Consequently, cross-comparing ecosystem metrics derived from the EwE model with those derived from observations is important to understand how accurately the EwE model may capture ecosystem structure.

Trophic level (TL) is an essential concept in ecosystem studies, describing the vertical structure of the food web supporting top predators (Lindeman 1942). In a simplified food web, TL is defined as the number of feeding linkages separating an organism from primary producers (Thompson et al. 2007). In complex systems with a multitude of predator-prey interactions and (or) basal energy sources, TL can provide additional insight into consumer feeding strategies (Matich et al. 2011). TL is calculated by EwE using trophic linkages established based on aggregated dietary literature and can be estimated directly in an ecosystem using stable isotope (SI) analyses. SI ratios of nitrogen $\left(\delta^{15} \mathrm{~N}\right)$ measured in consumer tissues can be used to estimate relative TL because the heavy ${ }^{15} \mathrm{~N}$ isotope typically exhibits stepwise enrichment between predator and prey (DeNiro and Epstein 1981; Cabana and Rasmussen 1996). Thus, $\delta^{15} \mathrm{~N}$ has become a powerful tool for defining trophic relationships (e.g., Hobson and Welch 1992; Post 2002; Vanderklift and Ponsard 2003).

Here, we cross-validate CBS food-web reconstructions by comparing TL values estimated from the EwE model with those estimated from two widely used isotopic methods using observed $\delta{ }^{15} \mathrm{~N}$ values, one linear and one scaled by the value of $\delta^{15} \mathrm{~N}$ at a given TL (Post 2002; Hussey et al. 2014; Lassalle et al. 2014). In so doing, we evaluate the capacity of the EwE model to accurately represent trophic structure at an ecosystem scale (e.g., Prince William Sound, Alaska (Kline and Pauly 1998); Sørfjord, Norway (Nilsen et al. 2008); Mediterranean Sea (Navarro et al. 2011); Bay of Biscay, France (Lassalle et al. 2014)), even when diet data are lacking for specific taxa. We used the most comprehensive data set compiled for the Beaufort Sea Shelf to date to demonstrate relatively strong agreement on trophic hierarchy among models. While comparing TL calculations and agreement amongst modelling approaches, we also identify key sources of uncertainty and data gaps that contribute to inconsistencies among models.

\section{Materials and methods}

\section{Study area}

The Canadian Beaufort continental shelf is approximately $120 \mathrm{~km}$ wide and $530 \mathrm{~km}$ long (Carmack et al. 2004). The shelf is bordered by the Amundsen Gulf to the east and the Mackenzie Canyon to the west and descends steeply offshore into the Canada Basin (Fig. 1). Biological production on the Beaufort Shelf is strongly linked to circulation and ice cover that regulate bottom-up controls, including light and nutrient availability, vertical mixing, and stratification (Carmack and Wassmann 2006). The Mackenzie River has a dominant influence on the biophysical characteristics of the region by discharging large volumes of freshwater $\left(330 \mathrm{~km}^{2}\right.$ annually; Macdonald et al. 1998) and sediments onto the wide shelf. River discharge flows offshore to the shelf before moving eastwards and mixing with marine water, resulting in the co-occurrence of freshwater and marine biota (Carmack and Macdonald 2002). The ecosystem model and the SI data both represent the Beaufort Shelf up to a depth of $200 \mathrm{~m}$.

\section{Ecosystem overview}

The complexity of the Beaufort Sea ecosystem is linked to seasonal polar climate cycles that influence the residency and activity of animals (e.g., migratory marine mammals, marine birds, anadromous fishes, and ice-associated biota) and drive the spatial and temporal variability of energy sources that comprise the base of the food web (e.g., river discharge, phytoplankton blooms, cross-shelf exchange of organic matter and zooplankton; Carmack and Macdonald 2002; Williams and Carmack 2015). Knowledge of the roles and 
Fig. 1. Map of the Canadian Beaufort Shelf. The study area is outlined in black, defined by the $200 \mathrm{~m}$ contour along the shelf-break in Canadian waters. Reproduced from Hoover et al. (2021).

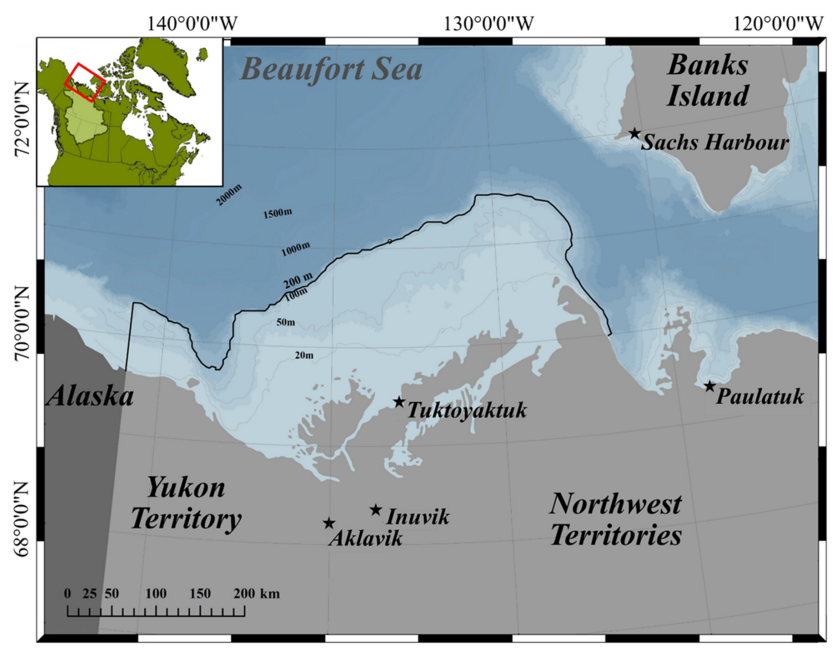

significance of many resident marine species for ecosystem structure and function remains limited (Cobb et al. 2008), but has recently improved as a result of ecosystem modelling exercises and dedicated ecosystem studies (e.g., Loseto et al. 2009; Connelly et al. 2014; Bell et al. 2016; Brewster et al. 2016a, 2016b, 2017; Giraldo et al. 2016; Majewski et al. 2016a; Stasko et al. 2016; Hoover et al. 2021). Detailed descriptions of CBS ecosystem structure can be found elsewhere (Carmack and Macdonald 2002; Cobb et al. 2008), but we provide a brief overview here for context in light of recent investigations.

Ice algae dominate winter primary production, which increases through the spring as daylight returns, and eventually gives way to a travelling pelagic marginal ice-edge bloom that follows the retreat of summer ice pack (Carmack and Macdonald 2002). During summer, pelagic phytoplankton form the majority of the food-web base (Carmack et al. 2004; Connolly et al. 2005). Although annual primary production is relatively low in the Beaufort Sea compared with other Arctic nearshore seas $\left(\sim 62 \mathrm{~g} \mathrm{C} \cdot \mathrm{m}^{-2} \cdot \mathrm{year}^{-1}\right.$; Ardyna et al. 2013), pelagic primary production is punctuated by upwelling events that replenish nutrients in surface layers and promote sudden, localized phytoplankton blooms (Carmack et al. 2004). Terrestrial organic carbon delivered by the Mackenzie River discharge can act as an additional basal carbon source (Bell et al. 2016). Heterotrophic bacteria and benthic algae contribute substantially to production in nearshore areas on the Mackenzie Shelf, but are minor sources at the regional scale (Garneau et al. 2006; Oxtoby et al. 2016). Significant macrophyte beds or kelp forests have not been identified in the region (Cobb et al. 2008).

Zooplankton diversity is low and spatially variable on the shelf due to the influence of the Mackenzie River plume (Darnis et al. 2008; Walkusz et al. 2010; Hunt et al. 2014). As elsewhere in the Arctic, lipid-rich zooplankton, pelagic amphipods, and krill act as important conduits of phytoplankton-derived energy to higher-trophic fish and marine mammals (e.g., Walkusz et al. 2012; Giraldo et al. 2016, 2018; Majewski et al. 2016b), but can also interrupt the delivery of pelagic production to benthic communities on the shelf. Benthic primary consumers may derive energy from pulsed inputs of phytodetritus during bloom events, lateral advection of organic matter via ocean currents, river discharge, or even directly from bacteria (e.g., Lovvorn et al. 2005; Renaud et al. 2007; Roy et al. 2015; 
Bell et al. 2016). The Mackenzie Shelf is typified by muddy-bottom benthic invertebrate communities, and biomass is dominated by echinoderms, bivalves, crustaceans, and annelids (Roy et al. 2014) that provide food for larger invertebrates, fish, and bottom-feeding marine mammals (Smith 1981; Lowry et al. 2004). Benthic invertebrate diversity and biomass is higher near the shelf-break compared with inshore (Conlan et al. 2008, 2013). Mobile benthopelagic carnivores and scavengers actively seek food in the water column and on the seafloor, and can act as integrators of the benthic and pelagic food-web pathways (e.g., Stasko et al. 2016; Giraldo et al. 2018), but there is still limited knowledge on how seasonally migrating demersal zooplankton contribute to benthic-pelagic energy transfer (Connelly et al. 2014).

To date, 55 marine and 20 coastal anadromous fish species have been reported in the CBS (shelf and slope; Coad and Reist 2018). Despite co-occurring in coastal waters during summer, brackish-water and anadromous fishes exhibit distinct resource partitioning along the freshwater-marine and benthic-pelagic continuums (Brewster et al. 2016a, 2016b). Offshore, Arctic cod (Boreogadus saida (Lepechin, 1774)) have been well studied due to their high relative abundance and are widely regarded as a key link between zooplankton (e.g., Walkusz et al. 2013; Majewski et al. 2016a, 2016b) and higher-trophic predators such as seals (Weslawski et al. 1994), birds (Matley et al. 2012), larger fish (Giraldo et al. 2018), and whales (Dehn et al. 2006). The diets of non-harvested and less abundant offshore fish species, which might be of considerable ecological importance (e.g., as potential food for top predators), are still poorly understood. From what is known, offshore fishes occupy a wide array of distinct functional feeding types and trophic levels, but generalist strategies within feeding types are common (e.g., Majewski et al. 2013, 2017; Walkusz 2013; Giraldo et al. 2016; Stasko et al. 2016) and are mostly benthic (Coad and Reist 2018).

Marine mammals are the top predators in the CBS and are culturally significant subsistence species. Large schooling fish and invertebrates form the major prey base supporting beluga whales (Delphinapterus leucas (Pallas, 1776)), ringed seals (Pusa hispida (Schreber, 1775)), and bearded seals (Erignathus barbatus (Erxleben, 1777)), which, along with bowhead whales (Balaena mysticetus Linnaeus, 1758), are the primary prey of Southern Beaufort polar bears (Ursus maritimus Phipps, 1774) (e.g., Bentzen et al. 2007; Loseto et al. 2009; Walkusz et al. 2012; Brewster et al. 2016a, 2016b; Yurkowski et al. 2016; Choy et al. 2017).

\section{EwE TL evaluation}

An existing EwE food-web model was used to estimate TL for 31 species groups ranging from primary producers to marine mammals (Suprenand et al. 2018; Hoover et al. 2021). Species groups were based on either single species or groups of species with similar life histories, feeding strategies, or common predators (Table 1, Fig. 2). Before more recent integrated research programs were completed within the study area (e.g., Bell et al. 2016; Brewster et al. 2016a, 2016b; Majewski et al. 2016a), an EwE model was used in a holistic assessment of the ecosystem. This model represented the 1970s Beaufort Sea shelf $(<200 \mathrm{~m})$ food web, with temporal (Ecosim) simulations from 1970-2012 capturing interannual dynamics (Suprenand et al. 2018; Hoover et al. 2021). As required for Ecopath model construction, basic input parameters included biomass, production-to-biomass ratio $(P / B)$, consumption-to-biomass ratio $(Q / B)$, ecotrophic efficiency (EE), and diet composition (eqs. 1 and 2). In order the fulfill the requirement of a mass-balanced model, the production $\left(P_{i}\right)$ for the first time step (the Ecopath model) of group $i$ is dependent on the biomass of predator group $j\left(B_{j}\right)$, the predation mortality of group $j\left(\mathrm{M} 2_{i j}\right)$, the fishery catch $\left(Y_{i}\right)$, the net migration rate $\left(E_{i}\right)$, biomass accumulation $\left(\mathrm{BA}_{i}\right)$, and the ecotrophic efficiency $\left(\mathrm{EE}_{i}\right)$ or proportion of production that is utilized by predation, fishing, and migration 
Table 1. Summary of the available nitrogen stable isotope (SI; $\delta^{15} \mathrm{~N}$ ) data for 31 species groups in the Canadian Beaufort Sea ecosystem, as well as the trophic levels (TLs) and relative trophic rankings estimated for each group by the Scaled SI Model, Linear SI Model, and Ecopath with Ecosim (EwE) Model.

\begin{tabular}{|c|c|c|c|c|c|c|c|c|c|c|c|}
\hline \multirow[b]{2}{*}{ Species group } & \multirow[b]{2}{*}{$\begin{array}{l}\text { Group } \\
\text { code }\end{array}$} & \multicolumn{5}{|c|}{ SI data available } & \multicolumn{3}{|c|}{ SI model results } & \multicolumn{2}{|c|}{$\begin{array}{l}\text { EwE Model } \\
\text { results }\end{array}$} \\
\hline & & $\begin{array}{l}\text { No. of } \\
\text { taxa }\end{array}$ & $\begin{array}{l}\text { No. of } \\
\text { entries }\end{array}$ & $\begin{array}{l}\text { Total } n \\
\text { (individual } \\
\text { samples) }\end{array}$ & $\begin{array}{l}\text { Weighted } \\
\text { mean } \delta^{15} \mathrm{~N}\end{array}$ & $\begin{array}{l}\text { Pooled } \\
\text { SD }\end{array}$ & $\begin{array}{l}\text { Scaled } \\
\text { TL }\end{array}$ & $\begin{array}{l}\text { Linear } \\
\text { TL }\end{array}$ & Rank & TL & Rank \\
\hline Polar Bears & POL & 1 & 23 & 476 & 20.14 & 0.71 & 8.04 & 5.28 & 1 & 4.81 & 1 \\
\hline Beluga Whales & BEL & 1 & 2 & 91 & 17.05 & 0.73 & 4.85 & 4.37 & 2 & 4.23 & 2 \\
\hline Ringed Seals & RSE & 1 & 1 & 33 & 16.90 & 0.56 & 4.75 & 4.33 & 3 & 3.83 & 3 \\
\hline Bearded Seals & BSE & 1 & 1 & 6 & 16.80 & 0.38 & 4.68 & 4.30 & 4 & 3.77 & 5 \\
\hline Birds & BIR & 9 & 21 & 365 & 15.25 & 0.69 & 3.84 & 3.84 & 5 & 3.82 & 4 \\
\hline Capelin & CAP & 1 & 1 & 17 & 14.70 & 0.41 & 3.59 & 3.68 & 6 & 3.45 & 8 \\
\hline Small Benthic Marine Fishes & SBF & 17 & 54 & 496 & 14.60 & 0.83 & 3.55 & 3.65 & 7 & 3.19 & 13 \\
\hline Small Nearshore Forage Fishes & SFF & 2 & 2 & 43 & 13.56 & 0.44 & 3.13 & 3.34 & 8 & 3.12 & 14 \\
\hline Flounders \& Benthic Cods & FLO & 4 & 6 & 351 & 13.54 & 0.88 & 3.12 & 3.34 & 9 & 3.32 & 10 \\
\hline Arctic Char and Dolly Varden & CHA & 2 & 11 & 176 & 13.46 & 0.82 & 3.09 & 3.31 & 10 & 3.60 & 6 \\
\hline Arctic \& Polar Cod & COD & 1 & 11 & 297 & 13.37 & 1.14 & 3.06 & 3.29 & 11 & 3.45 & 9 \\
\hline Bowhead Whales & BOW & 1 & 11 & 84 & 13.20 & 0.50 & 2.99 & 3.24 & 12 & 3.27 & 11 \\
\hline Echinoderms & ECH & 27 & 70 & 298 & 13.00 & 0.97 & 2.92 & 3.18 & 13 & 2.23 & 20 \\
\hline Other Salmonids & SAL & 3 & 3 & 96 & 12.60 & 0.89 & 2.78 & 3.06 & 14 & 3.56 & 7 \\
\hline Molluscs (not Bivalves) $b$ & MOL & 21 & 52 & 190 & 11.84 & 1.05 & 2.53 & 2.84 & 15 & 2.00 & 25 \\
\hline Arthropods & ART & 50 & 100 & 478 & 11.66 & 2.19 & 2.48 & 2.79 & 16 & 2.22 & 21 \\
\hline Macrozooplankton & MAC & 25 & 48 & 305 & 11.34 & 1.31 & 2.38 & 2.69 & 17 & 2.62 & 16 \\
\hline Worms & WOR & 39 & 71 & 324 & 11.24 & 1.19 & 2.35 & 2.66 & 18 & 2.07 & 24 \\
\hline Medium Copepods & MED & 3 & 11 & 76 & 10.80 & 0.75 & 2.22 & 2.53 & 19 & 2.12 & 22 \\
\hline Other Benthos & BEN & 18 & 35 & 106 & 10.64 & 1.10 & 2.17 & 2.49 & 20 & 2.08 & 23 \\
\hline Ciscoes \& Whitefish & CIS & 5 & 6 & 457 & 10.61 & 1.30 & 2.17 & 2.48 & 21 & 3.21 & 12 \\
\hline Jellies & JEL & 6 & 13 & 18 & 10.45 & 0.86 & 2.12 & 2.43 & 22 & 2.38 & 17 \\
\hline Large Copepods & COP & 5 & 10 & 70 & 9.74 & 1.42 & 1.93 & 2.22 & 23 & 2.27 & 19 \\
\hline Other Mesozooplankton & MES & 3 & 4 & 7 & 9.35 & 0.20 & 1.83 & 2.10 & 24 & 2.33 & 18 \\
\hline Bivalves $^{b}$ & BIV & 31 & 74 & 300 & 8.92 & 0.91 & 1.72 & 1.98 & 25 & 2.00 & 26 \\
\hline Microzooplankton $^{b}$ & MIC & 1 & 1 & 2 & 8.50 & 0.71 & 1.62 & 1.86 & 26 & 2.00 & 27 \\
\hline Pelagic Detritus ${ }^{a, b}$ & PDE & 1 & 3 & 22 & 5.59 & 0.85 & 1.00 & 1.00 & 27 & 1.00 & 28 \\
\hline Other Fishes & FIS & 1 & 1 & 6 & 5.52 & 0.59 & 0.99 & 0.98 & 28 & 3.06 & 15 \\
\hline Pelagic Primary Producers (all sizes) ${ }^{b}$ & PPP & 1 & 3 & 74 & 5.25 & 1.20 & 0.93 & 0.90 & 29 & 1.00 & 29 \\
\hline Benthic Detritus ${ }^{b}$ & BDE & 1 & 14 & 78 & 3.96 & 0.75 & 0.70 & 0.52 & 30 & 1.00 & 30 \\
\hline
\end{tabular}

Note: Data availability is summarized by the number of taxa represented within the group, number of individual entries of $\delta^{15} \mathrm{~N}$ data available in the literature $($ some representing means from published literature), total number of individual samples represented in the species group, mean $\delta^{15} \mathrm{~N}$ weighted by the sample size of each entry, and pooled standard means for

${ }^{a} \mathrm{TL}=1$ for Pelagic Detritus was assigned for the SI models, as a baseline for calculating TL for all other trophic groups.

${ }^{b} \mathrm{TL}=1$ was assigned to Pelagic Primary Producers, Pelagic Detritus, and Benthic Detritus groups for the EwE model (see eq. 4 ), resulting in $\mathrm{TL}=2$ for all primary consumers:

Microzooplankton, Bivalves, and Molluscs. 
Fig. 2. Schematic of feeding linkages and trophic levels (TLs) for 33 functional groups, estimated by the Ecopath with Ecosim model constructed for the Canadian Beaufort Shelf (Hoover et al. 2021). TLs are defined by vertical axes, and feeding linkages are represented by grey lines.

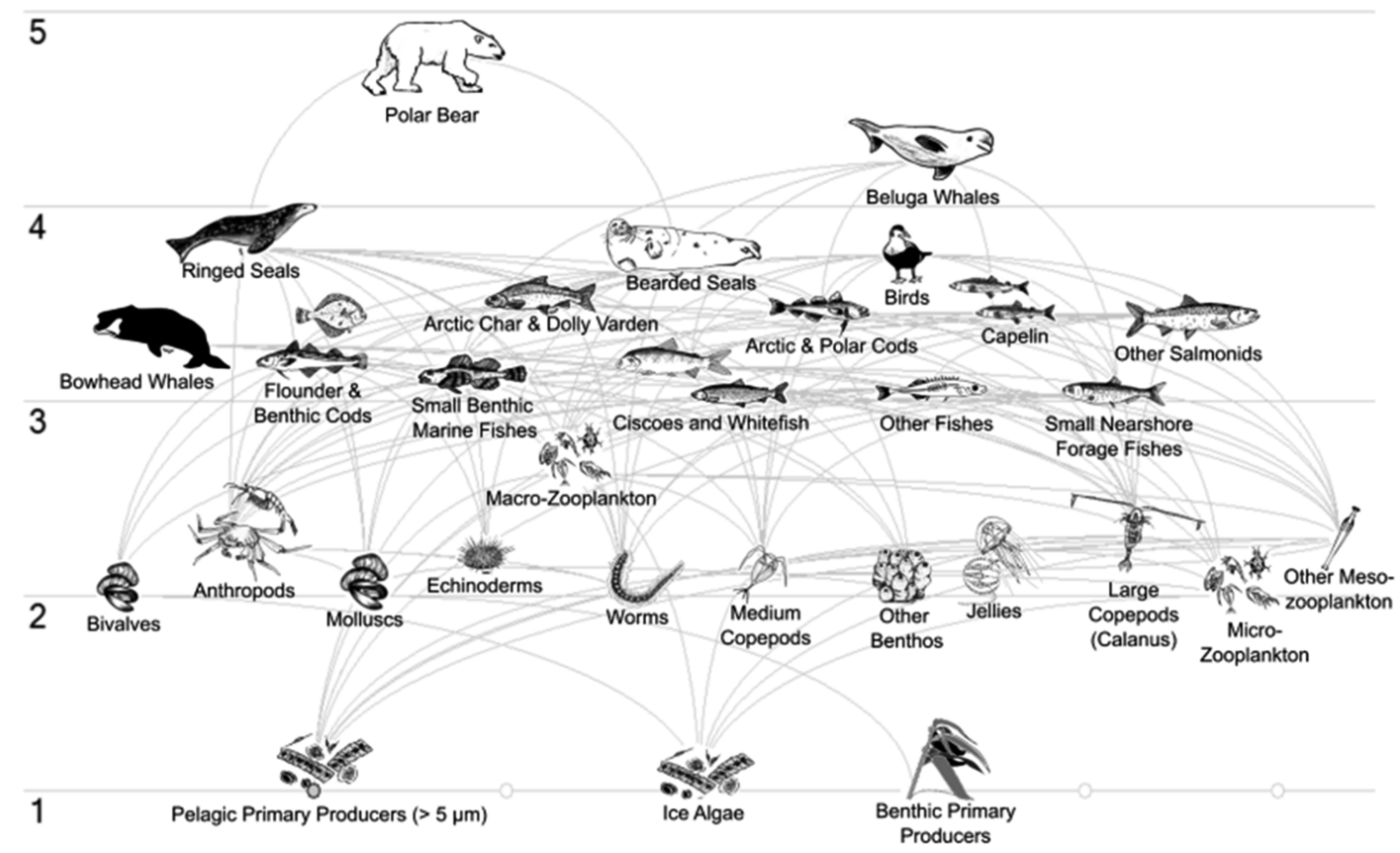

(Christensen and Walters 2004). The predation mortality can be re-expressed as the consumption of predator $j\left((Q / B)_{j}\right)$ combined with the proportion of prey group $i$ in the diet composition of predator $j\left(\mathrm{DC}_{j i}\right)$ (eq. 2).

Temporal simulations were created in Ecosim using eq. 3, where the biomass change in group $i$ biomass $\left(B_{i}\right)$ over time interval $d t\left(d B_{i} / d t\right)$ is dependent on the net growth efficiency $\left(g_{i}\right)$, total consumption on group $i\left(\Sigma_{j} Q_{j i}\right)$, total predation of all predators on group $i\left(\Sigma_{j} Q_{i j}\right)$, non-predation or other mortality $\left(\mathrm{MO}_{i}\right)$, the fishing mortality rate $\left(F_{i}\right)$, immigration rate $\left(I_{i}\right)$, and emigration rate $\left(e_{i}\right)$. Fitting of the historical model included sea ice (\% cover), sea-surface temperature $\left({ }^{\circ} \mathrm{C}\right)$, and harvest trends (biomass of harvested species each year). More extensive details on parameter calculations, including the inclusion of literature, expert understanding of the system, and workshop results is reported by Wieckowski et al. (2009), Hoover (2013), and Hoover et al. (2021). A summary of time-series data used in the model, including contributions to total model errors, are presented in the Supplementary Material (Supplementary Fig. $S 1^{2}$ ).

(1) $P_{i}=\Sigma_{j} B_{j} \times \mathrm{M} 2_{i j}+Y_{i}+E_{i}+\mathrm{BA}_{i}+P_{i} \times\left(1-\mathrm{EE}_{i}\right)$

(2) $B_{i} \times\left(\frac{P}{B}\right)_{i}=\Sigma_{j} B_{j} \times\left(\frac{Q}{B}\right)_{j} \times \mathrm{DC}_{j i}+Y_{i}+E_{i}+\mathrm{BA}_{i}+B_{i} \times\left(\frac{P}{B}\right)_{i} \times\left(1-\mathrm{EE}_{i}\right)$

(3) $\frac{d B_{i}}{d t}=g_{i} \Sigma_{j} Q_{j i}-\Sigma_{j} Q_{i j}+I_{i}-\left(M 0_{i}+F_{i}+e_{i}\right) B_{i}$

\footnotetext{
${ }^{2}$ Supplementary data are available with the article at https://doi.org/10.1139/as-2020-0035.
} 
(4) $\quad \mathrm{TL}_{j}=1+\Sigma \mathrm{DC}_{i j} \times \mathrm{TL}_{i}$

For each annual time step of the simulation, TL (eq. 4) is calculated based on the TL of each predator species $\left(\mathrm{TL}_{j}\right)$, the TL of each prey item $\left(\mathrm{TL}_{i}\right)$, and the proportion of each prey item (i) in the diet of predator $(j)$, represented as $\mathrm{DC}_{i j}$ (Christensen et al. 2005; Hoover et al. 2013). Species with completely herbivorous diets had a TL of 2 (Christensen et al. 2007). Proportional diet contributions were calculated for each species group based on literature available for the region or similar Arctic regions (e.g., deeper Beaufort Sea, Chukchi Sea, Amundsen Gulf, or other Arctic seas if necessary).

Diet information and species membership for each group are reported by Hoover et al. (2021), and a summary of dietary sources and types of data used in calculating diets are shown in Supplementary Table S2 ${ }^{2}$. Of the 73 dietary data sources noted for the EwE model (see Supplementary Table $S 2^{2}$ ), 12 references (16.4\%) summarize SI data, with 7 references (9.6\%) based on SI data from within the greater Beaufort Sea (including areas outside of model area and into Alaska). Of the remaining references used in creating the diet structure in the EwE model, 31 (42.5\%) summarize stomach contents, 9 (12.3\%) identify clearance rates and prey types of filter feeders, $3(4.1 \%)$ summarize fatty acid analyses, and $6(8.2 \%)$ are observational studies. When possible, dietary data from the model area was used. Of the dietary data sources, 29 (39.7\%) were from the Beaufort Sea in and around the model area, 32 (43.9\%) are from other Arctic ecosystems, and $12(16.4 \%)$ are from non-Arctic ecosystems. For species groups with no local dietary studies, expert knowledge was used if necessary, with some groups having the diets estimated by Hoover et al. (2021) if no better information was available. TL using the EwE approach utilizes the average TL value over the period 1970-2012.

\section{Nitrogen SI and TL calculations}

Nitrogen SI data were gathered from a collection of published and unpublished sources generated by field programs led by Fisheries and Oceans Canada and in collaboration with the University of Waterloo (Waterloo, Ontario, Canada) and University of Manitoba (Winnipeg, Manitoba, Canada). Data for offshore fishes, benthic invertebrates, and zooplankton were provided by the Beaufort Regional Environmental Assessment Marine Fishes Project (2012-2014; Stasko et al. 2017; C. Michel, unpublished data). Data for beluga whales, coastal marine fishes, and anadromous fishes were provided by the Arctic Coastal Ecosystem Study (Brewster et al. 2016a, 2016b, 2017) and various other riverine and coastal sampling programs (Tran 2014; McNicholl et al. 2018; M. Power and J. Reist, unpublished data). Detailed methodologies for SI analyses are outlined in the respective publications reported above, or else follow Stasko et al. (2017) for unpublished sources.

In addition, a standardized literature search was conducted to compile $\delta^{15} \mathrm{~N}$ data for species groups not represented in the field programs and to supplement the remaining groups. The Web of Science electronic database and Google Scholar were searched using the phrases "Beaufort Sea" OR "Western Arctic" AND " $\delta{ }^{15} N$ " OR "stable nitrogen". Publications were discarded if they did not include raw or averaged $\delta^{15} \mathrm{~N}$ data, did not report data for organisms captured on the Beaufort Sea Shelf and (or) adjacent regions, did not cover the period from 2013 and earlier (to match with EwE model), or contained data already captured by another publication. The only exception was the model group Birds, for which no $\delta^{15} \mathrm{~N}$ data were identified from the Beaufort Sea. Instead, data from Lancaster Sound were used as a representative for model cross-validation. All elemental SI ratios $\left({ }^{15} \mathrm{~N}:{ }^{14} \mathrm{~N}\right)$ were expressed in standard $\delta$ notation as parts per thousand (\%o) relative to the international standard atmospheric $\mathrm{N}_{2}$ for nitrogen (Mariotti 1983). The resulting database comprised 1039 entries of mean $\delta^{15} \mathrm{~N}$ by taxon, year, and (or) sample site from 
28 sources spanning the sampling period of 1983 to 2013 and is provided with references, relevant metadata, and detailed methodology for data compilation by Ehrman et al. (2021).

For the present study, only data reported from the Mackenzie or Alaska Beaufort Sea continental shelves $(<200 \mathrm{~m}$ depth) were included in analyses, to remain consistent with the existing EwE model and to limit variability from changes in taxonomic composition and trophic structure that exist for demersal communities beyond the shelf-break (e.g., Giraldo et al. 2016; Majewski et al. 2017; Stasko et al. 2018). Anadromous fish $\delta^{15} \mathrm{~N}$ values were only retained for individuals collected from coastal or riverine waters discharging into the Beaufort Sea. Lagoon fishes from the Alaskan portion of the Beaufort Sea were excluded because their $\delta^{15} \mathrm{~N}$ values were found to be $4 \%$ o lower than coastal fishes (Dunton et al. 2006). The remaining 642 entries of mean $\delta^{15} \mathrm{~N}$ values summarized 5342 individual samples and represented 282 taxa across 14 Phyla (Table 1). Entries were each assigned to one of the species groups defined by the EwE model (31 of 36 groups represented), weighted by their respective sample sizes reported in the literature (as raw data were often not provided), and used to calculate a weighted mean $\delta^{15} \mathrm{~N}$ for each group. A full list of species included in SI models can be found in the Supplementary Material (Supplementary Table $\mathrm{Si}^{2}$ ). Error for each group was expressed as a pooled standard deviation:

(5) $s_{\text {pooled }}=\sqrt{\frac{\left(n_{1}-1\right) s_{1}^{2}+\left(n_{2}-1\right) s_{2}^{2}+\ldots\left(n_{k}-1\right) s_{k}^{2}}{\left(\sum n_{1-k}\right)-k}}$

Trophic levels were calculated from weighted mean $\delta^{15} \mathrm{~N}$ data using two methods: the linear method developed by Post (2002) and a scaled method more recently proposed by Hussey et al. (2014), herein referred to as the "Linear SI Model" and "Scaled SI Model", respectively. The Linear SI Model assumes that the trophic enrichment of ${ }^{15} \mathrm{~N}$ between successive trophic levels $\left(\Delta^{15} \mathrm{~N}\right)$ can be treated as constant such that the TL of the consumer $\left(\mathrm{TL}_{\text {consumer }}\right)$ is calculated as follows:

(6) $\mathrm{TL}_{\text {consumer }}=\left(\frac{\delta^{15} \mathrm{~N}_{\text {consumer }}-\delta^{15} \mathrm{~N}_{\text {base }}}{\Delta^{15} \mathrm{~N}}\right)+\mathrm{TL}_{\mathrm{base}}$

where $\delta^{15} \mathrm{~N}_{\text {base }}$ is the $\delta^{15} \mathrm{~N}$ value of a representative baseline primary consumer with an assumed TL of $\mathrm{TL}_{\text {base }}$ (Post 2002). In this study, $\Delta^{15} \mathrm{~N}$ for the Linear SI Model was assumed to be $3.4 \%$ (Post 2002). However, empirical evidence and meta-analyses have shown that $\Delta^{15} \mathrm{~N}$ is negatively related to diet $\delta^{15} \mathrm{~N}$ values, such that the difference between the $\delta^{15} \mathrm{~N}$ value of a predator and its prey is smaller at higher levels in the food chain (e.g., Caut et al. 2008, 2009; Dennis et al. 2010). Trophic level was therefore additionally calculated using the Scaled SI Model, in which $\Delta^{15} \mathrm{~N}$ is dependent on the value of $\delta^{15} \mathrm{~N}$ for any given trophic level:

(7) $\mathrm{TL}_{\text {consumer }}=\left(\frac{\log \left(\delta^{15} \mathrm{~N}_{\text {lim }}-\delta^{15} \mathrm{~N}_{\text {base }}\right)-\log \left(\delta^{15} \mathrm{~N}_{\text {lim }}-\delta^{15} \mathrm{~N}_{\text {consumer }}\right)}{k}\right)+\mathrm{TL}_{\text {base }}$

where $\delta^{15} \mathrm{~N}_{\text {lim }}$ is the saturating isotope limit as TL increases and $k$ is a rate constant (Hussey et al. 2014). Values for the $\mu$ parameters $\delta^{15} \mathrm{~N}_{\text {lim }}$ and $k$ (21.93 and 0.31 , respectively) were taken from Hussey et al. (2014). Site-specific baseline normalization was not performed for this study because baseline data were not available from all literature studies. Instead, $\delta^{15} \mathrm{~N}_{\text {base }}$ for both SI models was set equal to the mean $\delta^{15} \mathrm{~N}$ of all Pelagic Detritus values $(5.59 \%$ $\pm 0.85 \%$ ) reported across the study region weighted by their reported sample sizes, assumed to occupy $\mathrm{TL}_{\text {base }}=1.0$. 
Table 2. Comparison of the coefficient of determination $\left(R^{2}\right)$ and Spearman's rank-order correlation coefficient $\left(r_{S}\right)$ from this study to those reported in similar Ecopath and stable isotope (SI) cross-validation studies in other marine ecosystems.

\begin{tabular}{llll}
\hline Study area & $R^{2}$ & $r_{S}$ & Reference \\
\hline Canadian Beaufort Sea & 0.84 & 0.83 & Present study: Linear SI Model \\
Canadian Beaufort Sea & 0.79 & 0.83 & $\begin{array}{l}\text { Present study: Scaled SI Model } \\
\text { Prince William Sound, USA }\end{array}$ \\
Northern Norway & & 0.97 & Kline and Pauly 1998 \\
Laguna de Rocha, Uruguay & 0.82 & 0.72 & Nilsen et al. 2008 \\
South Catalen Sea & & 0.69 & Milessi et al. 2010 \\
Core Sound, USA & 0.50 & & Deehr et al. 2014 \\
Xiamen Bay, China & 0.70 & & Du et al. 2015 \\
Bay of Biscay, France & & 0.72 & Lassalle et al. 2014 \\
Bitung area, Indonesia & & 0.71 & Du et al. 2020 \\
\hline
\end{tabular}

Note: The $R^{2}$ and $r_{S}$ for both SI model comparisons in this study were among the strongest of those previously reported.

\section{Comparison of SI and Ecopath results}

To assess the ability of the EwE model to capture overall trophic structure as the one generated by observed SI values, mean TLs estimated from the EwE model were linearly regressed against weighted mean TL calculated from Linear and Scaled SI methods, respectively. Studentized residuals were plotted and those larger than 3 were deemed outliers. Regressions were then repeated without outliers, and root mean squared errors (RMSE) were used to assess the impact of outlier groups on the predictive power of the EwE model. Analyses were repeated using Spearman's rank correlation analysis for two reasons: (1) to examine potential differences in the relative ranking of trophic group TLs by the three modelling approaches, regardless of linearity, and (2) to compare the correlation strengths of this study with those of similar studies conducted in other ecosystems (Table 2). The group Pelagic Detritus was excluded from regression and correlation analyses, as it was used for baseline normalization in SI models and was therefore not independent. Differences in the discrete TL assigned to each group by the two SI models were visualized in relation to $\delta^{15} \mathrm{~N}$ data using boxplots. Analyses and graphical procedures were performed in $\mathrm{R}$ version 3.6.0 ( $\mathrm{R}$ Core Team 2019).

\section{Results}

TLs estimated by the Ecopath Model were positively correlated with TLs estimated from both of the SI models, although relative rankings differed for some of the species groups (Table 1). All regressions between TL estimates derived from the EwE Model and SI models were positive and significant, with a stronger fit between the EwE Model estimates and Linear SI Model estimates (RMSE $=0.42$ ) as compared with the Scaled SI Model estimates $(\mathrm{RMSE}=0.48$; Fig. 3). The trophic group Other Fishes was identified as an outlier for both SI models, and the group Polar Bears was identified as an outlier for the Scaled SI Model only (studentized residuals $>3$; Figs. 3b, 3d). Regression fits were stronger for both SI models when outliers were excluded (Linear SI Model: slope $=1.01 \pm 0.08 \mathrm{SE}$, intercept $=0.08, F_{[1,27]}=168.25$, $R^{2}=0.86, p<0.001$, RMSE $=0.42$; Scaled SI Model: slope $=1.06 \pm 0.10 \mathrm{SE}$, intercept $=-0.19$, $F_{[1,26]}=107.92, R^{2}=0.81, p<0.001$, RMSE $=0.48$; Figs. $\left.3 a, 3 c\right)$ compared with when all trophic groups were considered (Linear SI Model: slope $=0.99 \pm 0.11 \mathrm{SE}$, intercept $=0.07$, $F_{[1,29]}=80.56, R^{2}=0.74, p<0.001$, RMSE $=0.56$; Scaled SI Model: slope $=1.28 \pm 0.16$ SE, intercept $\left.=-0.77, F_{[1,29]}=65.02, R^{2}=0.70, p<0.00, \mathrm{RMSE}=0.85\right)$. Removing outliers also improved 
Fig. 3. Linear regressions between trophic levels (TLs) calculated using the Ecopath with Ecosim (EwE) model and the Linear stable isotope (SI) model (a), and the Scaled SI model (c) for 29 of 33 trophic groups from the Canadian Beaufort Shelf. Solid lines represent observed linear relationships; dashed lines represent the 1:1 identity line. TLs calculated from both SI models were strongly related to those calculated from the EwE model, with a slightly stronger relationship with the Linear SI model. Detritus, assumed to be at $\mathrm{TL}=1$ in all models, was not included. The trophic group Other Fishes (FIS) was identified as an outlier using studentized residuals (threshold $=3$ ) from regressions with both the Scaled $(b)$ and Linear $(d)$ SI models, whereas the Polar Bear (POL) groups was identified as an outlier from the regression with the Scaled SI Model only. Outliers were removed from the regressions in Figs. $3 a$ and $3 c$, but are shown in white for contrast. See Table 1 for definitions of abbreviations used in Figs. $3 b$ and $3 d$.
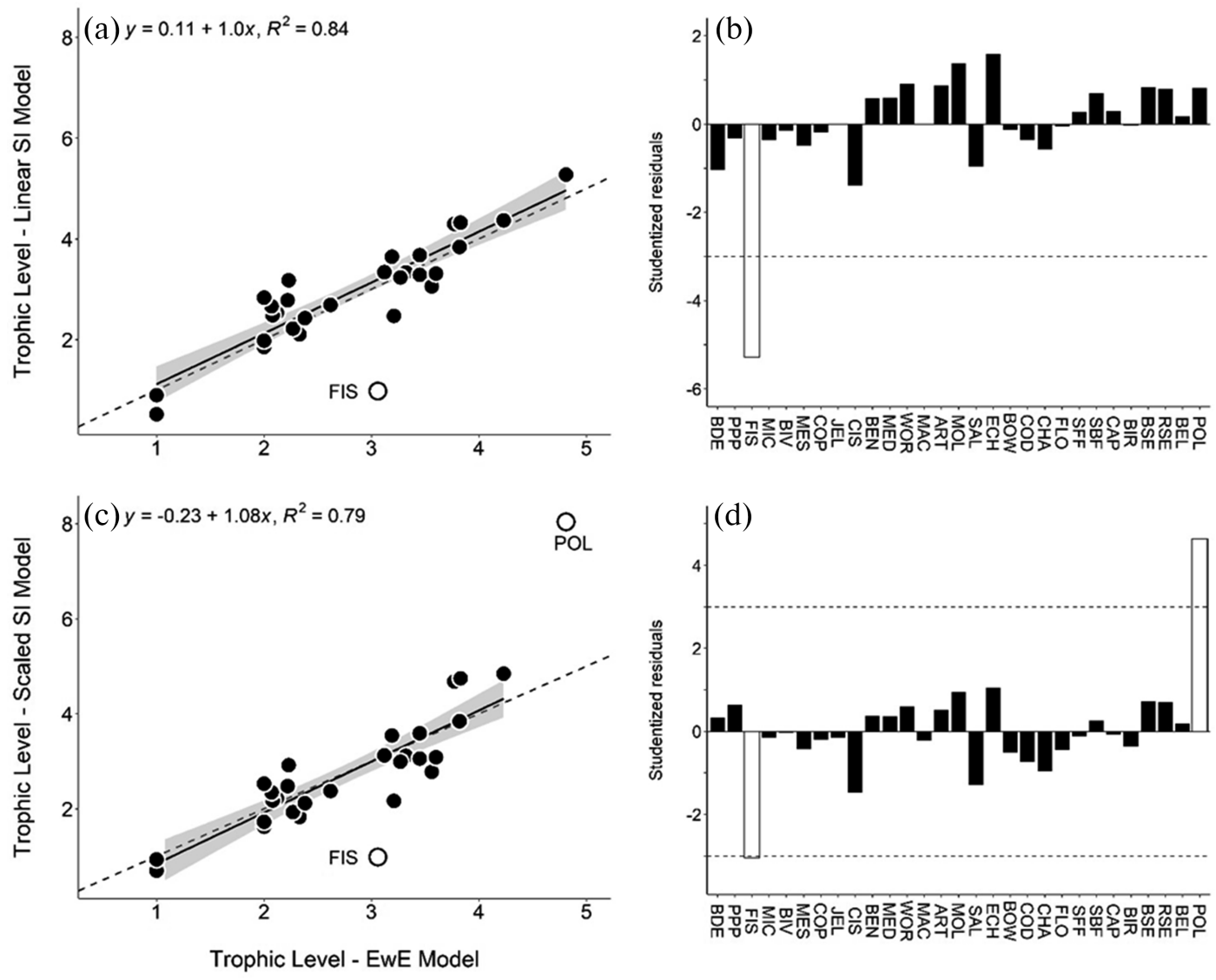

the normality of residuals (see Supplementary Fig. $S 1^{2}$ ). Residual and fitted values were uncorrelated (Supplementary Fig. S2 ${ }^{2}$ ).

TLs calculated from the Scaled SI Model occupied a larger range (1.11-8.08) than did those calculated from either the Linear SI Model (1.17-5.44) or the EwE model (1.0-4.81; Table 1). Notably, the two SI models produced the same relative rankings of species groups (Spearman's rank correlation, $r_{s}=1, p<0.001$; Fig. 4), although the Scaled SI Model consistently estimated higher TLs than did the Linear SI Model for groups at TL $>3$, and lower estimates for groups at TL $<3$ (Table 1; Fig. 5; see Discussion).

Marine mammal groups consistently ranked as the four highest members of the food web according to both SI models, with Polar Bears as the top predator followed by Ringed Seals, Bearded Seals, and Beluga Whales. Rankings from the EwE model were similar, but unlike the SI models, placed Birds at a similar TL as Bearded Seals and Ringed Seals. 
Fig. 4. Relationship between trophic levels (TLs) calculated using Linear and Scaled stable isotope (SI) models for 29 trophic groups from the Canadian Beaufort Shelf. The trophic group Pelagic Detritus, assumed to be at TL $=1$, was not included. Dashed line represents the 1:1 identity line. Rank order of TLs calculated from both models was the same; however, the Scaled SI Model tended to produce higher TL estimates for high-trophic animals than the Linear SI Model.

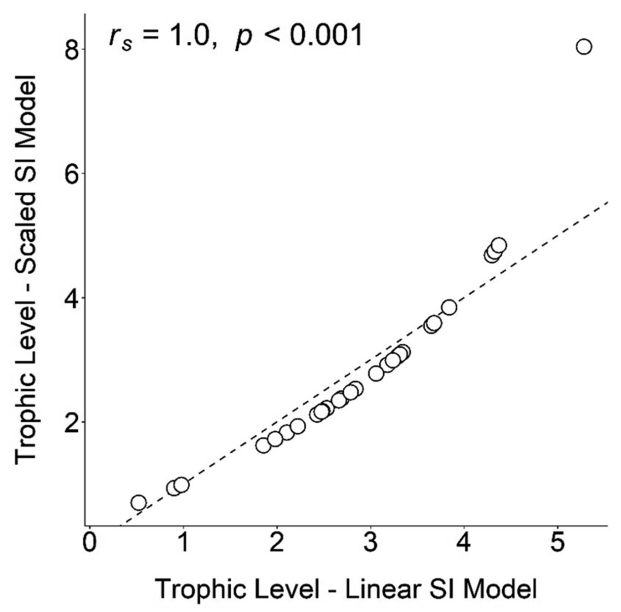

The only exception to the high TL estimated among marine mammal groups was Bowhead Whales, which ranked an entire TL lower than the seals and beluga according to SI models, and TL of $\sim 0.5$ according to the EwE model. The Scaled SI Model assigned Polar Bears to a much higher TL (8.04) than did either the Linear SI or EwE models (5.28 and 4.81, respectively). The assignment of Pelagic Primary Producers and Benthic Detritus to TL $\leq 1$ was in agreement among all models. However, the Other Fishes group, an outlier in both SI vs. EwE assessments, was also assigned to TL $<1$ by the SI models in contrast to being assigned to $\mathrm{TL}=3.06$ by the EwE Model. The EwE Model assigned primary consumers (i.e., Microzooplankton, Bivalves, and Molluscs) to TL $=2$, with other zooplankton and benthic groups ranging in TL from 2.07 (Worms) to 2.62 (Macrozooplankton), and fish groups ranging in TL from 3.06 (Other Fishes) to 3.60 (Arctic Char and Dolly Varden). SI models assigned Microzooplankton, Bivalves, Other Mesozooplankton, and Large Copepods to $\mathrm{TL}<2$, with other zooplankton and benthic groups ranging in TL from 2.12 (Jellies) to 2.9 (Echinoderms), and fish groups ranging in TL from 2.17 (Ciscoes and Whitefish) to 3.59 (Capelin) (Fig. 6).

\section{Discussion}

\section{Model performance}

Our results demonstrate the EwE model predicted mean TLs for most species groups that accord with inferences drawn directly from SI-based modelling approaches to a reasonable degree of accuracy, despite a lack of data on the diets and (or) distributions for some rare or understudied taxa (e.g., Echinoderms or Worms). Species groups with small differences between the EwE and SI models (i.e., low residuals) correspond to one of two categories. The first category was composed of species with well-known diets with multiple dietary data input studies (e.g., Beluga and Bowhead whales, and Capelin; see Supplementary Table S2 ${ }^{2}$; Hoover et al. 2021) that allowed for more accurate representation in the EwE model. Even for higher-trophic species with diverse diets, well-documented diet information contributed to a reduction in difference among modelling approaches. Primary 
Fig. 5. The $\delta^{15} \mathrm{~N}$ values collected from the literature for 30 trophic groups from the Canadian Beaufort Sea, in relation to the corresponding trophic levels (TLs) calculated from (a) the Linear stable isotope (SI) Model and (b) the Scaled SI Model. Horizontal lines indicate the $\delta^{15} \mathrm{~N}$ value corresponding to each discrete TL, and boxes are coloured according to the mean TL weighted by sample size. Boxes represent the interquartile range with a line at the median value and whiskers extending to the lowest and highest values within $1.5 \times$ of the interquartile range. Weighted mean TL, sample size, and species codes are presented in Table 1 . Both models produced the same rank order of trophic groups along the TL spectrum, but the Scaled SI Model produced lower TL estimates at $\mathrm{TL}<3$ and higher TL estimates at TL $>3$. Consequently, the groups Other Mesozooplankton (MES), Large Copepods (COP), Other Salmonids (SAL), Echinoderms (ECH), and Bowhead Whales (BOW) occupied different discrete TLs between the two models.

\section{(a) Linear SI Model}

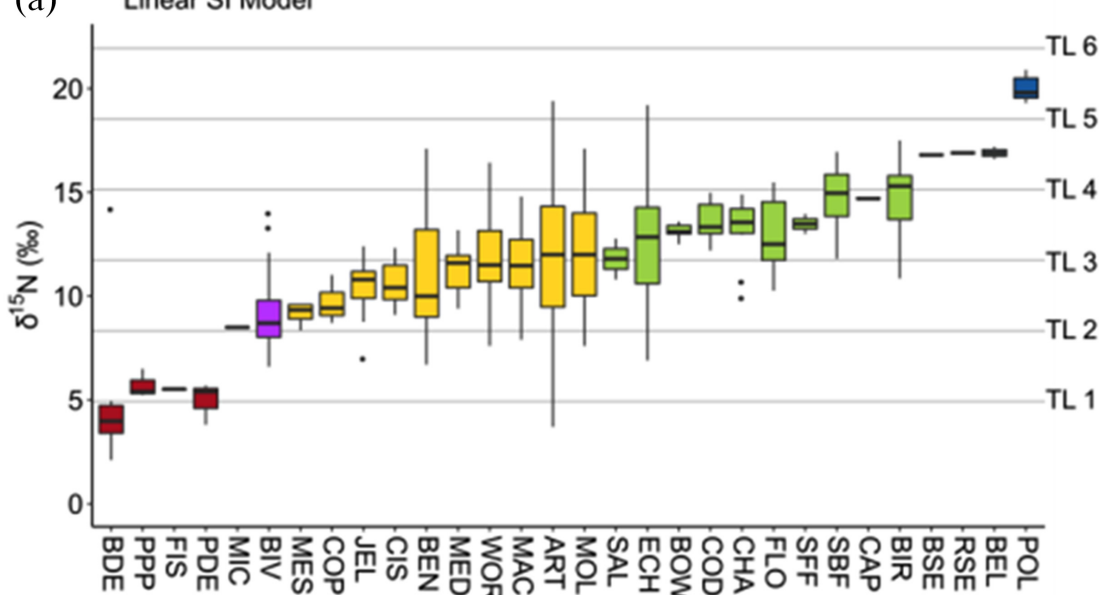

(b) Scaled SI Model

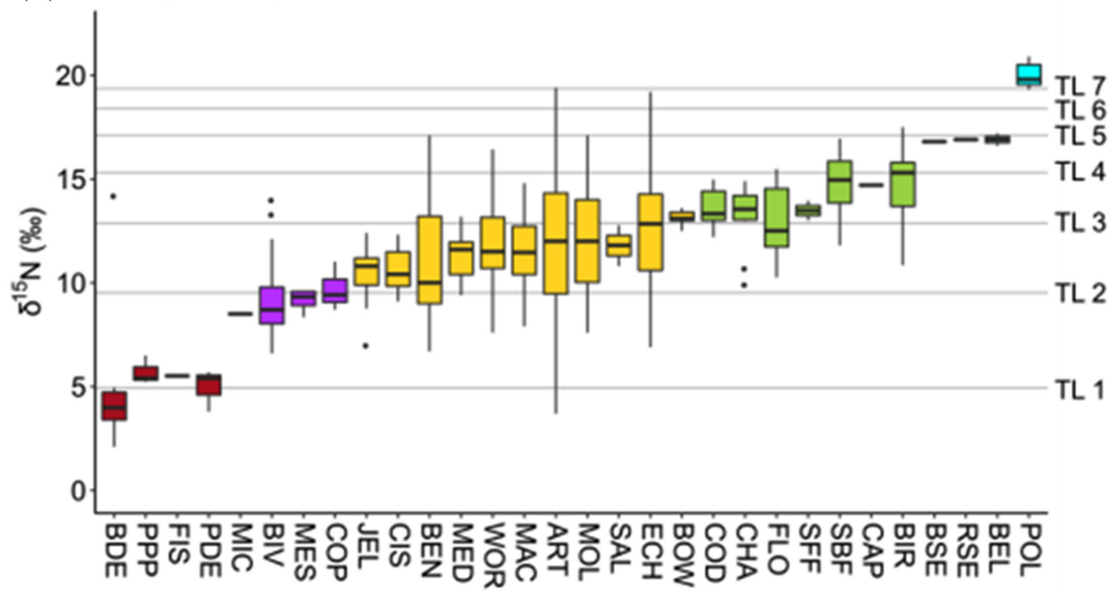

Weighted Mean TL

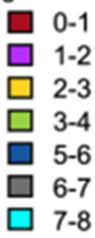

consumer groups (e.g., several zooplankton groups, Bivalves) near the base of the food web also showed small differences between the EwE and SI models, likely because their spectrum of food sources is narrower and more tightly linked to the basal resources used to define a TL of 1 . Consequently, diets of primary consumers would be expected to show lower variation in TL and $\delta^{15} \mathrm{~N}$ than would upper-trophic animals that may feed omnivorously across several TLs.

In contrast, EwE model TL predictions agreed less with SI model estimates for groups that aggregated species at coarse taxonomic levels with unknown and (or) sparse data on 
Fig. 6. Trophic levels (TLs) estimated by the Ecopath with Ecosim (EwE) Model compared with those estimated using the Linear and Scaled stable isotope (SI) models for 29 of 33 trophic groups. The trophic group Pelagic Detritus, assumed to be at $\mathrm{TL}=1$ for all models, was not included.

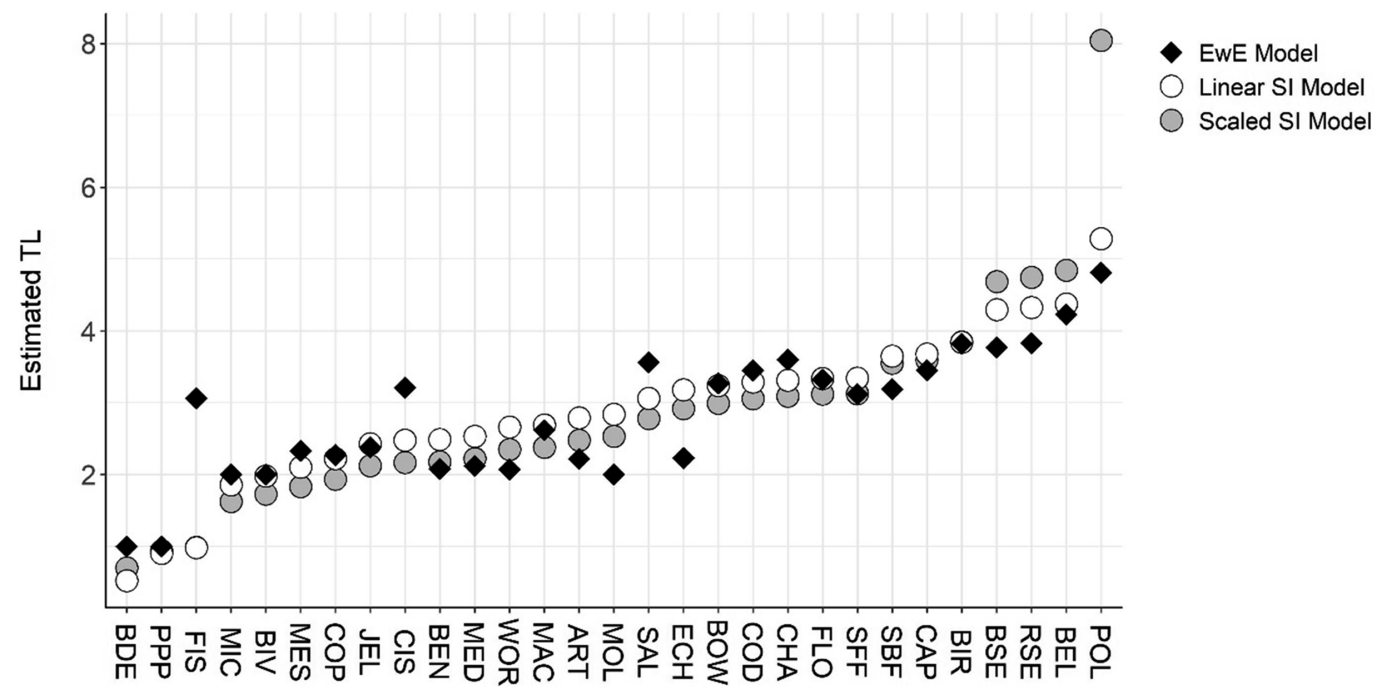

dietary patterns (e.g., Echinoderms, Molluscs, and Worms) and for anadromous fishes (Other Salmonids, Ciscoes and Whitefish, and Arctic Char and Dolly Varden). Aggregate groups encompassed taxa that could employ a range of feeding strategies from active predation to sedentary filter feeding (see further discussion in "Trophic aggregation choices" below). Indeed, some of these benthic species are facultative scavengers or predators depending on the conditions and can have high $\delta^{15} \mathrm{~N}$ as a result of microbial enrichment of ${ }^{15} \mathrm{~N}$ in detritus (e.g., Lovvorn et al. 2005). Similarly, estimates of TL for anadromous Cisco and Whitefishes and Other Salmonids groups were consistently lower for both SI models than for the EwE model. During the ice-free summer, some of these anadromous species disperse out of the Mackenzie River system (Gallaway et al. 1983; Reist and Bond 1988) to forage in coastal waters and eventually migrate back to freshwater before the freeze-up. Generally, species from these groups can be considered large, longer-lived fish with high dispersal capacities that potentially integrate diet and environmental fluctuations (e.g., terrestrial and (or) freshwater inputs) over large geographical scales (Coad and Reist 2018), which were not accounted for in the SI models. Our results highlight the importance of data resolution or quality in ecosystem modelling, as low-resolution data can lead to underestimations of TL for species whose diets and trophic connections are poorly documented.

Rank-order correlations between outputs from all model pairs were strong and in the same direction. This is a positive result, as over $60 \%$ of the studies used to inform the EwE trophic links were from outside the model area (see Supplementary Table S2 ${ }^{2}$ ). The vertical trophic structure of the CBS from this study was similar to that found by Hobson et al. (2002; Baffin Bay) with herbivorous copepods at TL of 2, Arctic Cod at TL of $\sim 3.5$, and Polar Bears at TL of $\sim 5$ indicating reasonably robust EwE and SI models based on known diets. The rank-order correlations between TLs calculated from the EwE and SI models for the Beaufort Sea (Table 2) are comparable with those reported for other high latitude areas $\left(r_{\mathrm{s}}=0.72\right.$ and 0.97 for Northern Norway and Prince William Sound, respectively; Kline and Pauly 1998; Nilsen et al. 2008) and within the range for other regions of the world 
$\left(r_{s}=0.69-0.97\right.$, Kline and Paul 1998; Nilsen et al. 2008; Navarro et al. 2011; Lassalle et al. 2014; Du et al. 2020; $R^{2}=0.50-0.82$, Milessi et al. 2010; Deehr et al. 2014; Du et al. 2015).

\section{Trophic aggregation choices}

In food-web modelling, species are often combined into logical functional groups to facilitate the understanding of complex structure and dynamics of trophic networks (Allesina and Pascual 2009). Trophic aggregation was necessary for a study of this magnitude, and was based on general habitat preferences (e.g., benthic vs. pelagic), general ecology, stomach content data (from literature), taxonomy, and a conceptual food-web model created by ecosystem experts (Wieckowski et al. 2009). Recent work has highlighted the strong influence that taxonomy has in determining the structure of food webs (Eklöf et al. 2012; Gray et al. 2015), but some of the species groups used to construct the EwE model were at such high-order taxonomic aggregation that they likely masked substantial feeding diversity. For example, fish (Order Actinopterygii) were divided into nine different feeding groups, whereas all echinoderms were aggregated into a single Phylum-level species group, and the Worms group contained multiple Phyla. As deeper understanding of the structure and function of the ecosystem is available, aggregating groups by feeding habit (e.g., filter feeders, mobile predators, benthic deposit feeders) is an alternative approach that may capture bottom-up trophic linkages better. However, grouping by feeding habit may lose resolution from a top-down approach and presents aggregation problems of its own (e.g., both fish and some amphipods may be considered mobile carnivores, but likely occupy very different trophic levels). Despite these limitations, the error between EwE and SI TL estimates was $<0.5$ for most groups, leading to rank-order correlations that were among the strongest reported for similar studies in the literature (Table 2). The impacts of poorly aggregated groups can be seen in the outlier group Other Fishes (FIS). This group is likely an outlier due to the fact that during EwE model construction, this group served as a catch-all for any fish identified to be within the model area, but lacking knowledge on significance to the food web. SI data were only available for a single species in the Other Fishes group, biasing the SI-derived TL estimate to reflect a single, low-TL species. Since the time of model development (2012-2014), extensive studies have been completed, allowing for improved re-development of the model in the future. Thus, the current EwE model provided a fairly accurate representation of the trophic hierarchy observed on the CBS and could provide insight into the trophic role of species that were not represented in this study (rare species and (or) species with limited data available).

Aggregation of species also has an effect on the TL calculations for all methods and their comparative assessment. The EwE TLs range from 1 to 4.81, while the SI models range from 0.52 to 8.02. As dictated by eq. 4 for the EwE Model, all producers are assigned a TL of 1 , and all primary consumers a TL of 2 (Christensen et al. 2007), with no values greater than 1, but less than 2 possible. This artifact of comparing multiple methodologies is explicit in the discrepancies between the minimum TL values. For SI models, values lower than 2 are possible for primary consumers, with the additional possibility of capturing multiple feeding strategies for these lower-trophic benthos or zooplankton. From an SI perspective, combining species into functional groups has the potential to increase isotopic variability of the aggregate compared with the species' component (Phillips et al. 2005). However, this effect is somewhat mitigated by the increased sample size that results from data pooling and is reflected by the relatively low standard deviation of the weighted mean $\delta^{15} \mathrm{~N}$ for most species groups.

Unlike SI, EwE methods calculate TL for the group as a whole, rather than averaging multiple values. Moreover, cannibalism must be limited in EwE model balancing and fitting (Christensen et al. 2005), such that aggregated groups are significantly limited or unable to 
feed on others within their grouping in the model, and diets are shifted to other species groups. This simplification can lead to underestimation of TLs, especially for aggregate groups. While all aggregate groups within the EwE model are potentially impacted, zooplankton and benthic aggregate groups with multiple feeding strategies are likely impacted the greatest. Multiple life histories, feeding strategies, and taxa are combined into single model groupings, and the model does not account for multiple predator-prey interactions or cannibalism that are likely occurring within the groups. This and other simplifications of the food web collapses the range of lower trophic levels, limiting their TL variability, and thereby reducing the TL of higher-level predators in the process. Furthermore, once EwE model predator-prey pathways are set in the Ecopath model, new pathways cannot be added in the future (e.g., adding new prey items), thus potentially limiting increases in a species prey diversity over time. The addition of these interactions in the food web would increase the TL of lower TL groups and expand the total range of TLs represented in the EwE model.

As noted, aggregation of species influences the TL values, variation, and ranges and is unavoidable in assessing the food web in its entirety. For these reasons, we caution against use of higher-level aggregated ecosystem information, to inform specific, species-level decisions that would require further knowledge on species-specific foraging strategies, behaviour, and life-history traits. The growing attention to biological traits analysis is making taxon-specific feeding information more widely accessible (particularly for marine benthic invertebrates; Degen and Faulwetter 2019), and future modelling efforts may benefit from the ability to make further trophically relevant group divisions that include functional diversity.

\section{SI model comparison}

Although the TL rankings calculated from the Linear and Scaled SI models were the same, closer inspection of the species for which model predictions did substantially differ gave some insight into the appropriateness of each model. In particular, the Scaled SI Model-estimated Polar Bear TL (8.08) is $>2.5$ TLs higher relative to those estimated by both the Linear SI (5.44) and EwE models (4.81). This was not unexpected, as Hussey et al. (2014) argue that the primary advantage of the Scaled SI Model is to correct a bias toward underestimating the TL of top predators. However, such a large discrepancy suggests that, in this case, the Scaled SI Model may be truly overestimating rather than correcting a bias. A TL of $\sim 5$ for polar bears is consistent with current literature estimates and known feeding habits (e.g., Hobson et al. 2002; Bentzen et al. 2007). Moreover, the TLs estimated for Bearded and Ringed Seals, which make up the majority of Polar Bear diet in the Beaufort region (e.g., Bentzen et al. 2007), were between 3.77 and 4.87 using all models. It is highly unlikely that Polar Bears are 3-4 TL higher than their main prey.

The overestimation of Polar Bear TL may be a result of the underlying model assumption that $\Delta^{15} \mathrm{~N}$ declines with increasing consumer $\delta^{15} \mathrm{~N}$ in aquatic food webs (Hussey et al. 2014; Supplementary Fig. $\mathrm{S}^{2}{ }^{2}$ ). The simplest ecological explanation for the phenomenon is that trophic omnivory is common in size-structured aquatic systems. Generally, larger predators that are higher in the food chain consume prey from a larger range of trophic levels (e.g., Scharf et al. 2000), such that the $\Delta^{15} \mathrm{~N}$ between them and their prey is averaged across multiple lower TLs. Polar bears, in contrast, are specialized predators that feed almost exclusively on seals. In this case, we suggest the underlying assumption of the Linear SI Model is more appropriate. Thus, the Scaled SI Model may overestimate TL when top predators have specialized feeding habits. The comparison highlights that neither SI Model may be "better" than the other. Rather, an investigator should carefully consider how well the underlying assumptions are satisfied by the ecosystem of interest when choosing which model to use. 


\section{Conclusions and significance of the work}

This study analyzes one of the largest data sets for the western Canadian Arctic food web from the coast to $200 \mathrm{~m}$ depth, to provide a comprehensive overview of the vertical trophic structure. EwE modelling efforts drew on a variety of formal and informal sources to construct the first comprehensive ecosystem assessment for the region, cross-validated by 642 observations of mean $\delta^{15} \mathrm{~N}$ representing 5342 individual samples across 282 taxa (Ehrman et al. 2021). Correspondence between TL measurements calculated either by EwE or SI models has increased confidence in our understanding of the CBS food-web structure, setting a baseline upon which future studies can build and refine. We demonstrated that an EwE model, constructed with minimal local diet data, can be used to calculate reliable proxies of TL that compare directly with sample-based estimates, underscoring the utility of the modelling framework for drawing conclusions about the possible ecological consequences of large-scale environmental change for the CBS.

Trophic groups that require more baseline data or special considerations to refine the understanding of food-web structure are highlighted. These specifically include understudied aggregate groups (e.g., Other Fish, Echinoderms) and anadromous fishes (e.g., Cisco and Whitefishes and Other Salmonids) including their role in the marine system. Such information is directly applicable to the conservation objectives and subsequent monitoring efforts of the Tarium Nyrutait Marine Protected Area in the Beaufort Sea, and the Anguniaqvia niqiqyuam Marine Protected Area in the neighbouring Amundsen Gulf. Conservation objectives for both marine protected areas underscore the importance of maintaining food-web integrity, for which this study confirms a baseline food-web structure. Although caution is generally warranted when using TL as an ecosystem indicator for migratory species that link ecosystems and (or) integrate energy sources over vast geographical distances (e.g., Watt and Ferguson 2015; Brewster et al. 2016a, 2016b), the work here demonstrates the issue may be a larger concern for anadromous fishes, migratory seabirds, and highly aggregated poorly studied groups than for migratory marine mammals on the Beaufort Shelf (Bowhead and Beluga Whales). The harvests of anadromous fish by the Inuit represent a significant part of their diet. Understanding how these mobile species mediate food-web stability and connectivity between shallow marine and fresh waters (e.g., Jardine et al. 2012), remains a challenge for devising ecosystem monitoring in the CBS and conservation strategies in the Arctic.

Additionally, lower model agreement on TLs for aggregate mid- to lower-TL species groups (Other Fishes, Echinoderms, Arthropods, and Molluscs) indicates that the choice of taxa for monitoring within these groups is important. The selection of specific indicator species, or a small group of functionally similar species is likely to yield more informative monitoring data than monitoring broadly defined aggregate groups. Although technically the same principal should apply to zooplankton, strong agreement in TLs among models suggests size-fractioned zooplankton samples may suffice for monitoring relative TLs but requires further investigation to confirm.

The Beaufort Sea Shelf region is culturally and economically important for local communities, contains areas of significant conservation value, and is susceptible to socioeconomic uncertainties due to global climate change and climate variability. Agreement of TLs across the trophic hierarchy from multiple methods provides a benchmark to assess potential changes in ecosystem structure and biotic interactions associated with future changing environmental conditions (Schmidt et al. 2017). Future studies to better define the aggregate groupings will increase precision in present-day TL estimates, while repeat sampling in the future will allow the data presented to be used in assessments of future ecosystem changes. 


\section{References}

Allesina, S., and Pascual, M. 2009. Food web models: a plea for groups. Ecol. Lett. 12: 652-662. doi: 10.1111/j.14610248.2009.01321.x. PMID: 19453619.

Ardyna, M., Babin, M., Gosselin, M., Devred, E., Bélanger, S., Matsuoka, A., and Tremblay, J.E. 2013. Parameterization of vertical chlorophyll $a$ in the Arctic Ocean: Impact of the subsurface chlorophyll maximum on regional, seasonal, and annual primary production estimates. Biogeosciences, 10: 4383-4404. doi: 10.5194/bg10-4383-2013.

Bell, L.E., Bluhm, B.A., and Iken, K. 2016. Influence of terrestrial organic matter in marine food webs of the Beaufort Sea shelf and slope. Mar. Ecol. Prog. Ser. 550: 1-24. doi: 10.3354/meps11725.

Bentzen, T.W., Follmann, E.H., Amstrup, S.C., York, G.S., Wooller, M.J., and O’Hara, T.M. 2007. Variation in winter diet of southern Beaufort Sea polar bears inferred from stable isotope analysis. Can. J. Zool. 85: 596-608. doi: 10.1139/Z07-036.

Brewster, J.D., Giraldo, C., Choy, E.S., Macphee, S.A., Hoover, C., Lynn, B., et al. 2017. A comparison of the trophic ecology of Beaufort Sea Gadidae using fatty acids and stable isotopes. Polar Biol. 41: 149-162. Springer Berlin Heidelberg. doi: 10.1007/s00300-017-2178-0.

Brewster, J.D., Giraldo, C., Swanson, H., Walkusz, W., Loewen, T.N., Reist, J.D., et al. 2016a. Ecological niche of coastal Beaufort Sea fishes defined by stable isotopes and fatty acids. Mar. Ecol. Prog. Ser. 559: 159-173. doi: $10.3354 /$ meps11887.

Brewster, J.D., Giraldo, C., Swanson, H., Walkusz, W., Loewen, T.N., Reist, J.D., et al. 2016b. Ecological niche of coastal Beaufort Sea fishes defined by stable isotopes and fatty acids. Mar. Ecol. Prog. Ser. 559: 159-173. doi: 10.3354/meps11887.

Buszowski, J., Christensen, V., Gao, F., Hui, J., Lai, S., Steenbeek, J., et al. 2007. Ecopath with Ecosim 6.

Cabana, G., and Rasmussen, J.B. 1996. Comparison of aquatic food chains using nitrogen isotopes. Proc. Natl. Acad. Sci. USA. 93: 10844-10847. PMID: 8855268.

Carmack, E., and Wassmann, P. 2006. Food webs and physical-biological coupling on pan-Arctic shelves: Unifying concepts and comprehensive perspectives. Prog. Oceanogr. 71: 446-477. doi: 10.1016/j.pocean.2006.10.004.

Carmack, E.C., and Macdonald, R. 2002. Oceanography on the Canadian Shelf of the Beaufort Sea: A setting for marine life. Arctic 55: 29-45.

Carmack, E.C., Macdonald, R.W., and Jasper, S. 2004. Phytoplankton productivity on the Canadian Shelf of the Beaufort Sea. Mar. Ecol. Prog. Ser. 277: 37-50. doi: 10.3354/meps277037.

Caut, S., Angulo, E., and Courchamp, F. 2008. Discrimination factors $\left(\Delta^{15} \mathrm{~N}\right.$ and $\left.\Delta^{13} \mathrm{C}\right)$ in an omnivorous consumer: effect of diet isotopic ratio. Funct. Ecol. 22: 255-263. doi: 10.1111/j.1365-2435.2007.0.

Caut, S., Angulo, E., and Courchamp, F. 2009. Variation in discrimination factors $\left(\Delta^{15} \mathrm{~N}\right.$ and $\left.\Delta^{13} \mathrm{C}\right)$ : the effect of diet isotopic values and applications for diet reconstruction. J. Appl. Ecol. 46: 443-453. doi: 10.1111/j.13652664.2009.01620.x.

Choy, E.S., Rosenberg, B., Roth, J.D., and Loseto, L.L. 2017. Inter-annual variation in environmental conditions affect the prey and body condition of eastern Beaufort Sea Beluga whale (Delphinapterus leucas) population. Mar. Ecol. Prog. Ser. 579: 213-225. doi: 10.3354/meps12256.

Christensen, V., and Walters, C. 2004. Ecopath with Ecosim: methods, capabilities and limitations. Ecol. Modell. 172: 109-139.

Christensen, V., Walters, C., Pauley, D., and Forrest, R. 2007. Ecopath with Ecosim version 6.0: User manual/ help files guide. Lenfest Oceans Futures Project, University of British Columbia, British Columbia, Canada.

Christensen, V., Walters, C., and Pauly, D. 2005. Ecopath with Ecosim: a user's guide Version 5. Fisheries Centre: University of British Columbia.

Coad, B.W., and Reist, J.D. 2018. Marine Fishes of Arctic Canada. University of Toronto Press.

Cobb, D., Fast, H., Papst, M.H., Rosenberg, D., Rutherford, R., and Sareault, J.E. 2008. Beaufort Sea Large Ocean Management Area : Ecosystem Overview and Assessment Report. Fisheries and Oceans Canada.

Colléter, M., Valls, A., Guitton, J., Gascuel, D., Pauly, D., and Christensen, V. 2015. Global overview of the applications of the Ecopath with Ecosim modeling approach using the EcoBase models repository. Ecol. Modell. 302: 42-53. doi: 10.1016/j.ecolmodel.2015.01.025.

Conlan, K., Aitken, A., Hendrycks, E., McClelland, C., and Melling, H. 2008. Distribution patterns of Canadian Beaufort shelf macrobenthos. J. Mar. Syst. 74: 864-886.

Conlan, K., Hendrycks, E., Aitken, A., Williams, B., Blasco, S., and Crawford, E. 2013. Macrofaunal biomass distribution on the Canadian Beaufort Shelf. J. Mar. Syst. 127: 76-87. doi: 10.1016/j.jmarsys.2013.07.013.

Connelly, T.L., Deibel, D., and Parrish, C.C. 2014. Progress in Oceanography Trophic interactions in the benthic boundary layer of the Beaufort Sea shelf, Arctic Ocean: Combining bulk stable isotope and fatty acid signatures. Prog. Oceanogr. 120: 79-92. doi: 10.1016/j.pocean.2013.07.032.

Connolly, R.M., Gorman, D., and Guest, M.A. 2005. Movement of carbon among estuarine habitats and its assimilation by invertebrates. Oecologia, 144: 684-691. doi: 10.1007/s00442-005-0167-4. PMID: 16001216.

Darnis, G., Barber, D.G., and Fortier, L. 2008. Sea ice and the onshore-offshore gradient in pre-winter zooplankton assemblages in southeastern Beaufort Sea. J. Mar. Syst. 74: 994-1011.

Deehr, R.A., Luczkovich, J.J., Hart, K.J., Clough, L.M., Johnson, B.J., and Johnson, J.C. 2014. Using stable isotope analysis to validate effective trophic levels from Ecopath models of areas closed and open to shrimp trawling in Core Sound, NC, USA. Ecol. Model. 282: 1-17. doi: 10.1016/j.ecolmodel.2014.03.005.

Degen, R., and Faulwetter, S. 2019. The Arctic Traits Database - A repository of Arctic benthic invertebrate traits. Earth Syst. Sci. Data, 11: 301-322. doi: 10.5194/essd-11-301-2019. 
Dehn, L., Follmann, E.H., Rosa, C., Duffy, L.K., Thomas, D.L., Bratton, G.R., et al. 2006. Stable isotope and trace element status of subsistence-hunted bowhead and beluga whales in Alaska and gray whales in Chukotka. Mar. Pollut. Bullet. 52: 301-319. doi: 10.1016/j.marpolbul.2005.09.001.

DeNiro, M., and Epstein, S. 1981. Influence of diet on the distribution of nitrogen isotopes in animals. Geochim. Cosmochim. Acta 45: 341-351. doi: 10.1016/0016-7037(81)90244-1.

Dennis, C.A., Macneil, M.A., Rosati, J.Y., Pitcher, T.E., and Fisk, A.T. 2010. Diet discrimination factors are inversely related to $\delta^{15} \mathrm{~N}$ and $\delta^{13} \mathrm{C}$ values of food for fish under controlled conditions. Rapid Commun. Mass Spectrom. 24: 3515-3520. doi: 10.1002/rcm. PMID: 21080502.

Du, J., Cheung, W.W.L., Zheng, X., Chen, B., Liao, J., and Hu, W. 2015. Comparing trophic structure of a subtropical bay as estimated from mass-balance food web model and stable isotope analysis. Ecol. Model. 312: 175-181. doi: 10.1016/j.ecolmodel.2015.05.027.

Du, J., Makatipu, P.C., Tao, L.S.R., Pauly, D., Cheung, W.W.L., Peristiwady, T., et al. 2020. Comparing trophic levels estimated from a tropical marine food web using an ecosystem model and stable isotopes. Estuarine, Coast. Shelf Sci. 233: 106518. doi: 10.1016/j.ecss.2019.106518.

Dunton, K.H., Weingartner, T., and Carmack, E.C. 2006. The nearshore western Beaufort Sea ecosystem: Circulation and importance of terrestrial carbon in arctic coastal food webs. Prog. Oceanogr. 71: 362-378. doi: 10.1016/ j.pocean.2006.09.011.

Eklöf, A., Helmus, M.R., Moore, M., and Allesina, S. 2012. Relevance of evolutionary history for food web structure. Proc. R. Soc. B Biol. Sci. 279: 1588-1596. doi: 10.1098/rspb.2011.2149.

Ehrman, A., Hoover, C., Giraldo, C.S.AM., Brewster, J.D., Michel, C., Reist, J.D., et al. 2021. A meta-collection of nitrogen stable isotope data measured in Arctic marine organisms from the Canadian Beaufort Sea, 1983-2013. BMC Res. 14: 347. doi: 10.1186/s13104-021-05743-0.

Frainer, A., Primicerio, R., Kortsch, S., Aune, M., Dolgov, A.V., Fossheim, M., and Aschan, M.M. 2017. Climate-driven changes in functional biogeography of Arctic marine fish communities. Proc. from Natl. Acad. Sci. United states Am. 114: 18-20. doi: 10.1073/pnas.1706080114.

Gallaway, B.J., Griffiths, W.B., Craig, P.C., Gazey, W.J., and Helmericks, J.W.1983. An assessment of the Colville River Delta stock of Arctic cisco - migrants from Canada? Pap. Univ. Alaska, 21: 4-23.

Garneau, M.È., Vincent, W.F., Alonso-Sáez, L., Gratton, Y., and Lovejoy, C. 2006. Prokaryotic community structure and heterotrophic production in a river-influenced coastal arctic ecosystem. Aquat. Microb. Ecol. 42: 27-40. doi: 10.3354/ame042027.

Giraldo, C., Stasko, A., Choy, E.S., Rosenberg, B., Majewski, A., Power, M., et al. 2016. Trophic variability of Arctic fishes in the Canadian Beaufort Sea: a fatty acids and stable isotopes approach. Polar Biol. 39: 1267-1282. doi: 10.1007/s00300-015-1851-4.

Giraldo, C., Stasko, A., Walkusz, W., Majewski, A., Rosenberg, B., Power, M., et al. 2018. Feeding of Greenland halibut (Reinhardtius hippoglossoides) in the Canadian Beaufort Sea. J. Mar. Syst. 183: 32-41. doi: 10.1016/ j.jmarsys.2018.03.009.

Gray, C., Figueroa, D.H., Hudson, L.N., Ma, A., Perkins, D., and Woodward, G. 2015. Joining the dots: An automated method for constructing food webs from compendia of published interactions. Food Webs, 5: 11-20. The Authors. doi: 10.1016/j.fooweb.2015.09.001.

Hobson, K., and Welch, H. 1992. Determination of trophic relationships within a high Arctic marine food web using $\delta 13 \mathrm{C}$ and $\delta 15 \mathrm{~N}$ analysis. Mar. Ecol. 84: 9-18.

Hobson, K.A., Fisk, A., Karnovsky, N., Holst, M., Gagnon, J., and Fortier, M. 2002. A stable isotope $\left(\delta^{13} C, \delta^{15} N\right)$ model for the North Water food web: implications for evaluating trophodynamics and the flow of energy and contaminants. Deep Sea Res. II 49: 5131-5150.

Hoegh-Guldberg, O., and Bruno, J.F. 2010. The impact of climate change on the world's marine ecosystems. Science, 328: 1523-8. doi: 10.1126/science.1189930. PMID: 20558709.

Hoover, C., Pitcher, T., and Christensen, V. 2013. Effects of hunting, fishing and climate change on the Hudson Bay marine ecosystem: I. Re-creating past changes 1970-2009. Ecol. Modell. 264: 130-142. doi: 10.1016/ j.ecolmodel.2013.01.010.

Hoover, C.A. 2013. Ecosystem Model Indicators for the Beaufort Sea Shelf Region of the Beaufort Sea Shelf. Can. Data Report Fish. Aqua. Sci. 1249.

Hoover, C.A., Walkusz, W., MacPhee, S., Nieme, A., Majewski, A., and Loweto, L. 2021. Canadian Beaufort Sea shelf food web structure and changes from 1970-2012. Can. Data Rep. Fish. Aquat. Sci. Available from https://sciencecatalogue.canada.ca/record $=4094705 \sim$ S6.

Hunt, B.P.V., Nelson, R.J., Williams, B., McLaughlin, F.A., Young, K.V., Brown, K.A., et al. 2014. Zooplankton community structure and dynamics in the Arctic Canada Basin during a period of intense environmental change (2004-2009). J. Geophys. Res. Ocean. 119: 2518-2538. doi: 10.1002/2013JC009156.Received.

Hussey, N.E., MacNeil, M.A., Mcmeans, B.C., Olin, J.A., Dudley, S.F.J., Cliff, G., et al. 2014. Rescaling the trophic structure of marine food webs. Ecol. Lett. 17: 239-250. doi: 10.1111/ele.12226. PMID: 24308860.

Jardine, T.D., Pusey, B.J., Hamilton, S.K., Pettit, N.E., Davies, P.M., Douglas, M.M., et al. 2012. Fish mediate high food web connectivity in the lower reaches of a tropical floodplain river. Oecologia, 168(3): 829-838. PMID: 21983712.

Kline T.C., Jr., and Pauly, D. 1998. Cross-Validation of Trophic Level Estimates from a Mass-Balance Model of Prince William Sound Using 15N/14N Data. In Proceddings of the Internationl Symposium on Fishery Stock Assessment Models. Edited by T.J. Quinn II, F. Funk, J. Heifetz, J.N. Ianelli, J.E. Powers, J.F. Schweigert, et al. Alaska Sea Grant College Program Report No. 90-01. pp. 693-702. 
Kohlbach, D., Schaafsma, F.L., Graeve, M., Lebreton, B., Allen, B., David, C., et al. 2017. Strong linkage of polar cod (Boreogadus saida) to sea ice algae-produced carbon Evidence from stomach content, fatty acid and stable isotope analyses. Prog. Oceanogr. 152: 62-74. doi: 10.1016/j.pocean.2017.02.003.

Kortsch, S., Primicerio, R., Fossheim, M., Dolgov, A.V., and Aschan, M. 2015. Climate change alters the structure of arctic marine food webs due to poleward shifts of boreal generalists. Proc. R. Soc. B. 282: 20151546. doi: 10.1098/rspb.2015.1546.

Lassalle, G., Chouvelon, T., Bustamante, P., and Niquil, N. 2014. An assessment of the trophic structure of the Bay of Biscay continental shelf food web: Comparing estimates derived from an ecosystem model and isotopic data. Prog. Oceanogr. 120: 205-215. doi: 10.1016/j.pocean.2013.09.002.

Lindeman, R.L. 1942. The Trophic-Dynamic Aspect of Ecology. Ecology, 23: 399-417.

Loseto, L.L., Stern, G.A., Connelly, T.L., Deibel, D., Gemmill, B., Prokopowicz, A., et al. 2009. Summer diet of beluga whales inferred by fatty acid analysis of the eastern Beaufort Sea food web. J. Exp. Mar. Bio. Ecol. 374: 12-18. doi: 10.1016/j.jembe.2009.03.015.

Lovvorn, J.R., Cooper, L.W., Brooks, M.L., De Ruyck, C.C., Bump, J.K., and Grebmeier, J.M. 2005. Organic matter pathways to zooplankton and benthos under pack ice in late winter and open water in late summer in the north-central Bering Sea. Mar. Ecol. Prog. Ser. 291: 135-150. doi: 10.3354/meps291135.

Lowry, L.F., Sheffield, G., and George, J.C. 2004. Bowhead whale feeding in the Alaskan Beaufort Sea, based on stomach contents analyses. J. Cetacean Res. 6: 215-223.

Macdonald, R.W., Solomon, S.M., Cranston, R.E., Welch, H.E., Yunker, M.B., and Gobeil, C. 1998. A sediment and organic carbon budget for the Canadian Beaufort shelf. Mar. Geol. 144: 255-273. doi: 10.1016/S0025-3227(97) 00106-0.

Majewski, A., Atchison, S., Suchy, K., Henry, J., MacPhee, S., Walkusz, W., et al. 2016a. Beaufort Sea Marine Fishes Project - Update for Stakeholders. Fisheries and Oceans Canada, Ottawa, ON.

Majewski, A.R., Walkusz, W., Lynn, B.R., Atchison, S., Eert, J., Reist, J.D., and Sea, B. 2016b. Distribution and diet of demersal Arctic Cod, Boreogadus saida, in relation to habitat characteristics in the Canadian Beaufort Sea. Polar Biol. 39: 1087-1098. doi: 10.1007/s00300-015-1857-y.

Majewski, A.R., Lynn, B.R., Lowdon, M.K., Williams, W.J., and Reist, J.D. 2013. Community composition of demersal marine fishes on the Canadian Beaufort Shelf and at Herschel Island, Yukon Territory. J. Mar. Syst. 127: 55-64. doi: 10.1016/j.jmarsys.2013.05.012.

Majewski, A.R., Atchison, S., MacPhee, S., Eert, J., Niemi, A., Michel, C., and Reist, J.D. 2017. Marine fish community structure and habitat associations on the Canadian Beaufort shelf and slope. Deep. Res. Part I Oceanogr. Res. Pap. 121: 169-182. doi: 10.1016/j.dsr.2017.01.009.

Mariotti, A. 1983. Atmospheric nitrogen is a reliable standard for natural ${ }^{15} \mathrm{~N}$ abundance measurements. Lett. to Nat. 303: 685-687.

Matich, P., Heithaus, M.R., and Layman, C.A. 2011. Contrasting patterns of individual specialization and trophic coupling in two marine apex predators. J. Anim. Ecol. 80: 294-305. PMID: 20831730.

Matley, J.K., Fisk, A.T., and Dick, T.A. 2012. Seabird predation on Arctic cod during summer in the Canadian Arctic. Mar. Ecol. Prog. Ser. 450: 219-228. doi: 10.3354/meps09561.

Matley, J.K., Fisk, A.T., Dick, T.A., Matley, J.K., Fisk, A.T., and Dick, T.A. 2015. Foraging ecology of ringed seals (Pusa hispida), beluga whales (Delphinapterus leucas) and narwhals (Monodon monoceros) in the Canadian High Arctic determined by stomach content and stable isotope analysis. Polar Res. 34: 24295. doi: 10.3402/polar.v34.24295.

McNicholl, D., Davoren, G., Majewski, A., and Reist, J. 2018. Isotopic niche overlap between co-occurring capelin (Mallotus villosus) and polar cod (Boreogadus saida) and the effect of lipid extraction on stable isotope ratios. Polar Biol. 41: 423-432.

Milessi, A., Danilo, C., Laura, R.-G., Daniel, C., Javier, S., and Rodriguez-Gallego, L. 2010. Trophic mass-balance model of a subtropical coastal lagoon, including a comparison with a stable isotope analysis of the food-web. Ecol. Model. 221: 2859-2869. doi: 10.1016/j.ecolmodel.2010.08.037.

Navarro, J., Coll, M., Louzao, M., Palomera, I., Delgado, A., and Forero, M.G. 2011. Comparison of ecosystem modelling and isotopic approach as ecological tools to investigate food webs in the NW Mediterranean Sea. J. Exp. Mar. Bio. Ecol. 401: 97-104. doi: 10.1016/j.jembe.2011.02.040.

Nilsen, M., Pedersen, T., Nilssen, E.M., and Fredriksen, S. 2008. Trophic studies in a high-latitude fjord ecosystem a comparison of stable isotope analyses $\left(\delta^{13} \mathrm{C}\right.$ and $\left.\delta^{15} \mathrm{~N}\right)$ and trophic-level estimates from a mass-balance model. Can. J. Fish. Aquat. Sci. 65: 2791-2806. doi: 10.1139/F08-180.

Oxtoby, L.E., Mathis, J.T., Juranek, L.W., and Wooller, M.J. 2016. Estimating stable carbon isotope values of microphytobenthos in the Arctic for application to food web studies. Polar Biol. 39: 473-483. doi: 10.1007/s00300-015-1800-2.

Phillips, D.L., Newsome, S.D., and Gregg, J.W. 2005. Combining sources in stable isotope mixing models: alternative methods. Oecologia, 144: 520-527. doi: 10.1007/s00442-004-1816-8. PMID: 15711995.

Plaganyi, E.E. 2007. Models for an ecosystem approach to fisheries. FAO Fisher. Food and Agricultural Organization of the United Nations, Rome.

Plaganyi, E.E., and Butterworth, D.S. 2004. A critical look at the potential of Ecopath with Ecosim to assist in practical fisheries management. African J. Mar. Sci. 26: 261-287.

Post, D.M. 2002. Using Stable Isotopes to Estimate Trophic Position: Models, Methods, and Assumptions. Ecology, 83: 703-718.

R Core Team. 2019. R: A language and environment for statistical computing. R Foundation for Statistical Computing, Vienna, Austria. Available from https://www.R-project.org/. 
Reist, J.D., and Bond, W.A. 1988. Life history characteristics of migratory coregonids of the lower Mackenzie River, Northwest Territories, Canada. Finnish Fish. Res. 9: 133-144.

Renaud, P.E., Riedel, A., Michel, C., Morata, N., Gosselin, M., Juul-Pedersen, T., and Chiuchiolo, A. 2007. Seasonal variation in benthic community oxygen demand: A response to an ice algal bloom in the Beaufort Sea, Canadian Arctic? J. Mar. Syst. 67: 1-12. doi: 10.1016/j.jmarsys.2006.07.006.

Roy, V., Iken, K., and Archambault, P. 2014. Environmental drivers of the Canadian Arctic megabenthic communities. PLoS ONE, 9(7): e100900. doi: 10.1371/journal.pone.0100900.

Roy, V., Iken, K., Gosselin, M., Tremblay, J.-éric., Archambault, P., Ursulines, A., and Roy, V. 2015. Benthic faunal assimilation pathways and depth-related changes in food-web structure across the Canadian Arctic. Deep Sea Res. Part I Oceanogr. Res. Pap. 102: 55-71. Available from https://app.dimensions.ai/details/publication/ pub.1007685456.

Scharf, F.S., Juanes, F., and Rountree, R.A. 2000. Predator size - prey size relationships of marine fish predators : interspecific variation and effects of ontogeny and body size on trophic-niche breadth. Mar. Ecol. Prog. Ser. 208: 229-248.

Schmidt, N.M., Hardwick, B., Gilg, O., Høye, T.T., Krogh, P.H., Meltofte, H., et al. 2017. Interaction webs in arctic ecosystems: Determinants of arctic change? Ambio, 46: 12-25. doi: 10.1007/s13280-016-0862-x. PMID: 28116681.

Smith, T.G. 1981. Notes on the bearded seal, Erignathus barbatus, in the Canadian arctic. Government of Canada Fisheries and Oceans.

Stasko, A.D., Bluhm, B.A., Michel, C., Archambault, P., Majewski, A., Reist, J.D., et al. 2018. Benthic-pelagic trophic coupling in an Arctic marine food web along vertical water mass and organic matter gradients. Mar. Ecol. Prog. Ser. 594: 1-19. doi: 10.3354/meps12582.

Stasko, A.D., Swanson, H., Atchison, S., MacPhee, S., Majewski, A.R., De Montety, L., et al. 2017. Stable isotope data $\left(\delta^{15} \mathrm{~N}, \delta^{13} \mathrm{C}\right)$ for marine fishes and invertebrates from the Beaufort Regional Environmental Assessment Marine Fishes Project, August-September 2012 and 2013. Canadian Data Report of Fisheries and Aquatic Sciences.

Stasko, A.D., Swanson, H., Majewski, A., Atchison, S., Reist, J., and Power, M. 2016. Influences of depth and pelagic subsidies on the size-based trophic structure of Beaufort Sea fish communities. Mar. Ecol. Prog. Ser. 549: 153-166. doi: $10.3354 /$ meps11709.

Steenbeek, J., Buszowski, J., Christensen, V., Akoglu, E., Aydin, K., Ellis, N., et al. 2015. Ecopath with Ecosim as a model-building toolbox: Source code capabilities, extensions, and variations. Ecol. Modell. 319: 178-189. doi: 10.1016/j.ecolmodel.2015.06.031.

Suprenand, P.M., Ainsworth, C.H., and Hoover, C. 2018. Ecosystem Model of the Entire Beaufort Sea Marine Ecosystem: A Temporal Tool for Assessing Food-Web Structure and Marine Animal Populations from 1970 to 2014. Mar. Sci. Fac. Publ. 261. Available from https://scholarcommons.usf.edu/msc_facpub/261.

Thompson, R.M., Hemberg, M., Starzomski, B., and Shurin, J.B. 2007. Trophic Levels and Trophic Triangles: THe Prevalance of Omnivory in Real Food Webs. Ecology, 88: 612-617. PMID: 17503589.

Tran, L. 2014. Variations in Northern Dolly Varden (Salvelinus malma malma) total mercury concentrations from the northwestern Canadian Arctic. University of Waterloo.

Vanderklift, M.A., and Ponsard, S. 2003. Sources of variation in consumer-diet $\delta^{15} \mathrm{~N}$ enrichment: a meta-analysis. Oecologia, 136: 169-82. doi: 10.1007/s00442-003-1270-z. PMID: 12802678.

Walkusz, W., Majewski, A., and Reist, J.D. 2013. Distribution and diet of the bottom dwelling Arctic cod in the Canadian Beaufort Sea. J. Mar. Syst. 127: 65-75. doi: 10.1016/j.jmarsys.2012.04.004.

Walkusz, W., Paulić, J.E., Kwaśniewski, S., Williams, W.J., Wong, S., and Papst, M.H. 2010. Distribution, diversity and biomass of summer zooplankton from the coastal Canadian Beaufort Sea. Polar Biol. 33: 321-335. doi: 10.1007/s00300-009-0708-0.

Walkusz, W., Williams, W.J., Harwood, L.A., Moore, S.A., Stewart, B.E., and Kwasniewski, S. 2012. Compositionm biomass, and energetic content of biota in the vicinity of feeding bowhead whales (Balaena mysticetus) in the Cape Bathurst upwelling region (South eastern Beaufort Sea). DSRI I, 69: 25-35.

Walters, C., Pauly, D., and Christensen, C.V 1997. Structuring dynamic models of exploited ecosystems from trophic mass-balance assessments. Rev. Fish Biol. Fish. 7: 139-172. doi: 10.1023/a:1018479526149.

Wassmann, P., Duarte, C.M., Agustí, S., and Sejr, M.K. 2011. Footprints of climate change in the Arctic marine ecosystem. Glob. Chang. Biol. 17: 1235-1249. doi: 10.1111/j.1365-2486.2010.02311.x.

Watt, C.A., and Ferguson, S.H. 2015. Fatty acids and stable isotopes $\left(\delta^{13} \mathrm{C}\right.$ and $\left.\delta^{15} \mathrm{~N}\right)$ reveal temporal changes in narwhal (Monodon monoceros) diet linked to migration patterns. Mar. Mammal Sci. 31: 21-44. doi: 10.1111/mms.12131.

Weslawski, J.M., Ryg, M., Smith, T.G., and Oritsland, N.A. 1994. Diet of Ringed Seals (Phoca hispida) in a Fjord of West Svalbard. Arctic, 47: 109-114.

Wieckowski, K., Marmorek, D.R., Christensen, V., and Prekishot, D. 2009. Beaufort ERI: Integrated Ecosystem modeling workshop proceedings (Dec 15 to 17, 2009). Winnipeg, Manitoba.

Williams, W.J., and Carmack, E.C. 2015. The "interior" shelves of the Arctic Ocean: Physical oceanographic setting, climatology and effects of sea-ice retreat on cross-shelf exchange. Prog. Oceanogr. 139: 24-41. doi: 10.1016/ j.pocean.2015.07.008.

Yurkowski, D.J., Ferguson, S., Choy, E.S., Loseto, L.L., Brown, T.M., Muir, D.C.G., et al. 2016. Latitudinal variation in ecological opportunity and intraspecific competition indicates differences in niche variability and diet specialization of Arctic marine predators. Ecol. Evol. 6: 1666-1678. doi: 10.1002/ece3.1980. PMID: 26909143. 